Atmos. Chem. Phys., 17, 14559-14577, 2017

https://doi.org/10.5194/acp-17-14559-2017

(c) Author(s) 2017. This work is distributed under

the Creative Commons Attribution 4.0 License.

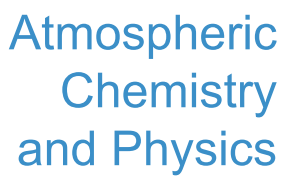

(c) (P)

\title{
Long-term profiling of mineral dust and pollution aerosol with multiwavelength polarization Raman lidar at the Central Asian site of Dushanbe, Tajikistan: case studies
}

\author{
Julian Hofer ${ }^{1}$, Dietrich Althausen ${ }^{1}$, Sabur F. Abdullaev ${ }^{2}$, Abduvosit N. Makhmudov ${ }^{2}$, Bakhron I. Nazarov $^{2}$, \\ Georg Schettler ${ }^{3}$, Ronny Engelmann ${ }^{1}$, Holger Baars ${ }^{1}$, K. Wadinga Fomba ${ }^{1}$, Konrad Müller ${ }^{1}$, Bernd Heinold ${ }^{1}$, \\ Konrad Kandler ${ }^{4}$, and Albert Ansmann ${ }^{1}$ \\ ${ }^{1}$ Leibniz Institute for Tropospheric Research, Leipzig, Germany \\ ${ }^{2}$ Physical Technical Institute of the Academy of Sciences of Tajikistan, Dushanbe, Tajikistan \\ ${ }^{3}$ Helmholtz Center Potsdam, German Research Center for Geosciences, Potsdam, Germany \\ ${ }^{4}$ Institut für Angewandte Geowissenschaften, Technische Universität Darmstadt, Darmstadt, Germany \\ Correspondence to: Julian Hofer (hofer@tropos.de)
}

Received: 15 June 2017 - Discussion started: 19 July 2017

Revised: 24 October 2017 - Accepted: 25 October 2017 - Published: 7 December 2017

\begin{abstract}
For the first time, continuous vertically resolved aerosol measurements were performed by lidar in Tajikistan, Central Asia. Observations with the multiwavelength polarization Raman lidar Polly ${ }^{\mathrm{XT}}$ were conducted during CADEX (Central Asian Dust EXperiment) in Dushanbe, Tajikistan, from March 2015 to August 2016. Co-located with the lidar, a sun photometer was also operated. The goal of CADEX is to provide an unprecedented data set on vertically resolved aerosol optical properties in Central Asia, an area highly affected by climate change but largely missing vertically resolved aerosol measurements. During the 18-month measurement campaign, mineral dust was detected frequently from ground to the cirrus level height. In this study, an overview of the measurement period is given and four typical but different example measurement cases are discussed in detail. Three of them are dust cases and one is a contrasting pollution aerosol case. Vertical profiles of the measured optical properties and the calculated dust and non-dust mass concentrations are presented. Dust source regions were identified by means of backward trajectory analyses. A lofted layer of Middle Eastern dust with an aerosol optical thickness (AOT) of 0.4 and an extinction-related Ångström exponent of 0.41 was measured. In comparison, two near-ground dust cases have Central Asian sources. One is an extreme dust event with an AOT of 1.5 and Ångström exponent of 0.12 and the other one is a most extreme dust event with an AOT of above
\end{abstract}

4 (measured by sun photometer) and an Ångström exponent of -0.08 . The observed lidar ratios (and particle linear depolarization ratios) in the presented dust cases range from 40.3 to $46.9 \mathrm{sr}$ (and $0.18-0.29$ ) at $355 \mathrm{~nm}$ and from 35.7 to $42.9 \mathrm{sr}$ $(0.31-0.35)$ at $532 \mathrm{~nm}$ wavelength. The particle linear depolarization ratios indicate almost unpolluted dust in the case of a lofted dust layer and pure dust in the near-ground dust cases. The lidar ratio values are lower than typical lidar ratio values for Saharan dust (50-60 sr) and comparable to Middle Eastern or west-Asian dust lidar ratios (35-45 sr). In contrast, the presented case of pollution aerosol of local origin has an Ångström exponent of 2.07 and a lidar ratio (particle linear depolarization ratio) of $55.8 \mathrm{sr}(0.03)$ at $355 \mathrm{~nm}$ and $32.8 \mathrm{sr}$ $(0.08)$ at $532 \mathrm{~nm}$ wavelength.

\section{Introduction}

Atmospheric mineral dust can be transported over tens of thousands of kilometers away from its arid or semi-arid source regions (Uno et al., 2009; Haarig et al., 2017). More observations, especially in western and Central Asia, are needed to describe global and regional dust transport and to estimate the effect of this dust on air quality (Chin et al., 2007), and climate, via direct and various indirect radiative effects. Extended investigations into Saharan 
dust close to its source regions (e.g., SAMUM-1, 2, Saharan Mineral Dust Experiment; Fennec climate programm; and SHADOW, Study of SaHAran Dust Over West Africa) (Heintzenberg, 2009; Ansmann et al., 2011a; Ryder et al., 2015; Veselovskii et al., 2016) as well as regarding dust longrange transport across the Atlantic ocean (e.g., SALTRACE, Saharan Aerosol Long-range Transport and Aerosol-CloudInteraction Experiment; Weinzierl et al., 2017) have been conducted to obtain novel data to reduce uncertainties in the above-mentioned estimations. However, the global dust belt, which reaches from the Sahara over the Arabian deserts to the Taklamakan and Gobi deserts, contains a lot more arid and semi-arid regions which act as sources for atmospheric mineral dust in the northern hemisphere (Darmenova et al., 2009; Ridley et al., 2016). This dust has a sensitive impact on climate, environmental conditions, ecosystems, and health. Central Asia lies in the middle of this global dust belt and contains some major dust sources (Fig. 1). Therefore, Central Asian countries are frequently affected by atmospheric mineral dust hazardous to respiratory health (Wiggs et al., 2003). Even bacteria, fungi, and viruses can be transported by dust over long distances (Griffin, 2007; Hara and Zhang, 2012; Yamaguchi et al., 2015; Park et al., 2016). Dust is also transported across the highly polluted Central Asia (Balance and Pant, 2003) further eastwards (Tanaka et al., 2005; Mikami et al., 2006) and on its way it is subject to stronger anthropogenic influence compared to the westward transport of Saharan dust (Bi et al., 2016).

Dust from different sources have different mineralogical compositions (Caquineau et al., 2002), different optical properties (Sokolik et al., 1993; Su and Toon, 2011; Schuster et al., 2012; Mamouri et al., 2013), and therefore different impacts on radiation and climate (Sokolik and Golitsyn, 1993; Golitsyn et al., 1993b; Nazarov et al., 2010a, b). Central Asia in particular is vulnerable to climate change and is already affected by it (Freedman and Neuzil, 2015; Lioubimtseva and Henebry, 2009; Xu et al., 2016). For example, dramatic glacier shrinking took place in the last decades in Tajikistan (Kayumov, 2010; Chatenoux, 2011), which has an effect on the water resources of Tajikistan and the whole Central Asian area (Chen et al., 2017). The links between mineral dust occurrence and climate change as well as possible feedbacks have to be quantified. Therefore, aerosol profiling in Central Asia is strongly required to better understand regional and global transport and deposition of mineral dust and its effects on radiation budget, cloud and precipitation development, and human health.

The sources and emission of dust in Central Asia, interaction with aerosol pollution, and climate relevant processes are investigated with models and satellite remote sensing $(\mathrm{Xi}$ and Sokolik, 2016, 2015a, b; Nobakht et al., 2015). Measurements with sun photometers, despite being rare in inland Central Asia (Klüser et al., 2015; Bayat et al., 2011), can provide column-integrated aerosol properties (Semenov et al., 2005; Bi et al., 2016; Chen et al., 2013). Addition- ally, vertically resolved information on aerosol optical properties are needed to thoroughly investigate radiative effects and dust-cloud interactions. The widely used satellite-borne lidar CALIPSO/CALIOP (Cloud-Aerosol Lidar and Infrared Pathfinder Satellite Observations/Cloud-Aerosol Lidar with Orthogonal Polarization) delivers snapshot-like observations in terms of backscatter profiles at 532 and $1064 \mathrm{~nm}$ wavelength. To estimate extinction coefficients of dust, the dust lidar ratio is required as an input, which introduces considerable uncertainty (e.g., Wandinger et al., 2010; Tesche et al., 2013; Amiridis et al., 2013). To obtain sophisticated sets of optical properties and detailed information on particle mixture and layering, long-range dust transport, multiday coherent structures, vertical mixing between the planetary boundary layer and lofted aerosol layers, aerosol-cloud interactions, and continuous observations with ground-based Raman lidars or HSRLs (High-Spectral-Resolution Lidars) are needed. Up to now, only a few experiments were performed to characterize the aerosol over Central Asia. In 1989 a Soviet-American research team conducted a joint experiment on dust in Tajikistan (Golitsyn and Gillette, 1993; Golitsyn et al., 1993a). Coordinated ground-based aircraft and satellite measurements took place during two dust storms on 16 and 20 September 1989. The total area occupied by the atmospheric dust during the latter dust storm was approximately $10^{5} \mathrm{~km}^{2}$ (Smirnov et al., 1993). The mass of dust in the air was estimated as $3.1 \mathrm{t}$ (Smirnov et al., 1994). Chemical analysis of the collected dust (Gomes and Gillette, 1993) showed a low iron content for Central Asian dust. A calcareous character and high contents of soluble salts were also observed (Miller-Schulze et al., 2011; Schettler et al., 2014; Groll et al., 2013; Andronova et al., 1993). In general, however, a very high variability (Andronova et al., 1993) lead to considerably different results depending on sampling location. Analysis of quartz filter samples collected in Dushanbe showed, besides significant amounts of dust, a strong contribution of anthropogenic black carbon pollution from fuel combustion and smoke (Hansen et al., 1993). Optical and radiative properties have been studied as well (Shukurov et al., 1993). Sokolik and Golitsyn (1993) performed radiative transfer calculations for the dust storms in 1989 and stated that the vertical distribution of additional total radiative heating rates can only be calculated with assumptions on vertically homogeneous optical properties and on the height of the dust layer. Sokolik et al. (1993) compared complex refractive indices from the dust collected in Tajikistan with dust from other sources. They found a seemingly different spectral behavior of the complex refractive index of Central Asian dust compared to Saharan dust, but Sokolik et al. (1993) concluded that there are large uncertainties and the discrepancies could be due to different measurement techniques. The measured aerosol optical thicknesses (AOTs) during those dust storms were up to 1.3 (Golitsyn and Gillette, 1993) and 3.3 at $550 \mathrm{~nm}$ (Pachenko et al., 1993), respectively. A few vertical profiles of the scattering coefficient of the dust were mea- 


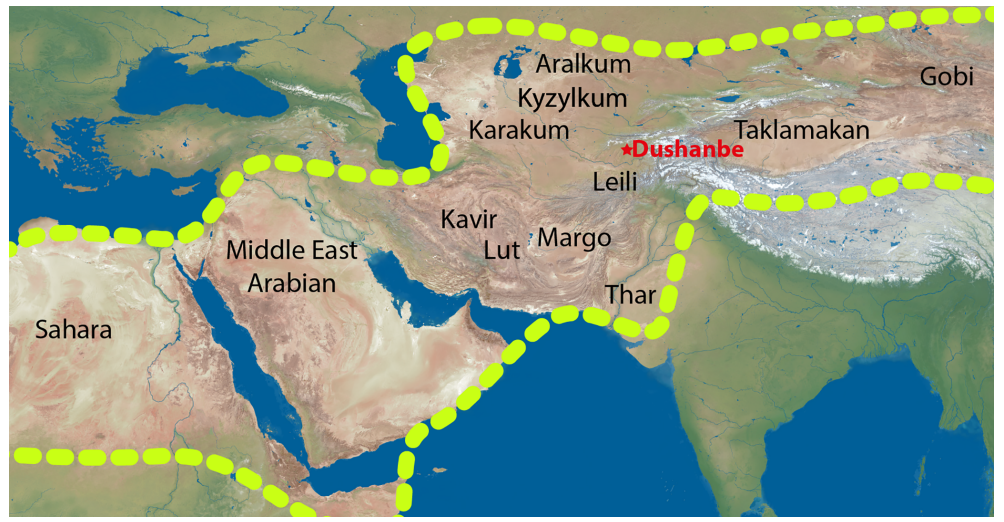

Figure 1. Geographical map with desert regions (black text), dust belt (bright green dashed line), measurement site in Dushanbe, Tajikistan (red text) highlighted (http://naturalearth.springercarto.com, adapted).

sured with a nephelometer on board an aircraft (Pachenko et al., 1993). These measurements showed that the majority of the dust was concentrated in the lowermost $3-3.5 \mathrm{~km}$ below a thermal inversion. Pachenko et al. (1993) mentioned dust plumes reaching through this inversion up to $6 \mathrm{~km}$ altitude. The measurements on 16 September 1989 also revealed a dust layer at a height of about $4 \mathrm{~km}$. Fraser (1993) used satellite data to obtain the horizontal distribution of the dust in Central Asia. Fraser (1993) emphasized the need for vertical profiles of the dust mass, which can be estimated from dust extinction coefficient, to determine the movement of the dust. Gillette et al. (1993) modeled dust deposition and transport during this 1989 campaign and mentioned the sensitivity of their model to the dust layer height, especially because of the complicated topography in Tajikistan.

Recently, a lidar station is operated in eastern Kyrgyzs$\tan$ (Chen and Sverdlik, 2007; Chen et al., 2013). For this station, Chen et al. (2013) report dust transported from the Aral Sea region, long-range transported dust from the Middle East and dust from the Taklamakan desert. A lidar is operated in Aksu (northwestern Taklamakan; Kai et al., 2008), where local dust was measured from ground to a height of $6 \mathrm{~km}$ during strong dust outbreaks (Tsunematsu et al., 2005) as well as lofted long-range transported dust layers at heights of $11 \mathrm{~km}$ (Mikami et al., 2006). Lidar measurements along the Caspian and Aral Sea region and Lake Balkhash in Kazakhstan were performed by Dieudonné et al. (2015). Dieudonné et al. (2015) showed that dust layers originating in the Caspian and Aral Sea region can regularly spread over wide areas of Russia and last for several days.

Nevertheless, the knowledge of the vertical aerosol distribution over Tajikistan and especially the transport of mineral dust over Central Asia is still insufficient. Therefore, the Central Asian Dust EXperiment (CADEX) was proposed. CADEX provides long-term data on vertical profiles of particle optical properties above Tajikistan. A multiwavelength polarization Raman lidar (Engelmann et al., 2016) was run continuously in Tajikistan over the 18-month period from March 2015 to August 2016. These measurements are part of the Polly ${ }^{\text {NET }}$ (Baars et al., 2016), which is an attempt to contribute to the establishment of a ground-based polarization Raman lidar network (e.g., Baars, 2011; Kanitz et al., 2013; Giannakaki et al., 2016), with the aim to support regional and global dust modeling.

This article provides an overview of the observations and focuses mainly on four exemplary measurement cases, which show typical but differing scenarios of atmospheric mineral dust in Tajikistan. The vertical profiles of the measured particle optical properties, calculations of the dust mass concentration, and backward trajectories for the individual cases are presented. In a follow-up publication, a summary of the key findings of the CADEX campaign including a statistical analysis of the entire measurement period will be provided.

In Sect. 2 of this article, the CADEX campaign, the measurement site, the lidar system, and the auxiliary data are described. Section 3 gives an overview of the observations and the four exemplary measurement cases are presented in detail. The cases are compared and discussed in Sect. 4.

\section{The Central Asian Dust EXperiment (CADEX) and instruments}

CADEX was a joint German-Tajik project to investigate the atmospheric mineral dust over Tajikistan. The goal of the project was to provide a not-yet-available data set of optical and microphysical properties of Central Asian mineral dust on a longer-term basis. The data are used to characterize and investigate the particle types, possible aerosol sources, and the aerosol influence on the radiation budget in Central Asia.

Tajikistan lies in the global dust belt in close proximity of some major dust sources like the Taklamakan desert, the Aralkum desert of the desiccating Aral Sea, the Kyzylkum and Karakum deserts east of the Caspian Sea, the Iranian Dasht-e Kavir and Dasht-e Lut deserts and the deserts in 
Afghanistan (Fig. 1). Therefore, Tajikistan is frequently affected by severe dust events and is a net accumulator of dust (Gillette and Dobrowolski, 1993). Tajikistan is a country with a dry continental climate and benefits from its water resources. Melt water discharge from the high mountain regions ensures a high freshwater availability. Furthermore, Central Asia and especially Tajikistan are highly affected by climate change. For example, dramatic glacier shrinking took place in the last decades (Makhmadaliev and Novikov, 2002; Makhmadaliev et al., 2004, 2008; Kayumov and Novikov, 2014). This could also have an effect on the water resources of Tajikistan and the whole Central Asian area in the future since the regionally important rivers such as the Amu Darya and Syr Darya are fed by glacier and snow melt water (Siegfried et al., 2012; Sorg et al., 2014), which are feeding the desiccating Aral Sea, which now itself became a strong dust source (Xi and Sokolik, 2016). Furthermore, deposited dust and anthropogenic black carbon themselves can accelerate glacier melt by altering the glacier's surface albedo (Gabbi et al., 2015; Schmale et al., 2017).

The fieldwork of CADEX included column-integrating sun photometer measurements, vertically resolved lidar measurements, and meteorological observations in Dushanbe, Tajikistan. The lidar observations were carried out in Dushanbe at the Poligon measurement site of the Physical Technical Institute of the Academy of Sciences of Tajikistan. The measurement site lies in an urban environment on a hill in the eastern part of Dushanbe. The lidar is installed in front of a laboratory and office building (Fig. 2a). Its coordinates are $38^{\circ} 33^{\prime} 34^{\prime \prime} \mathrm{N}, 68^{\circ} 51^{\prime} 22^{\prime \prime} \mathrm{E}$, and its altitude is $864 \mathrm{~m}$ a.s.l. The measurement campaign lasted from 17 March 2015 until 31 August 2016. On 487 days during that period, lidar data have been acquired for a duration of at least $3 \mathrm{~h}$. On 308 of these days the lidar ran even longer than $20 \mathrm{~h}$.

In addition, the field experiment is accompanied by 3-D regional modeling with the regional dust model COSMOMUSCAT (Wolke et al., 2012; Heinold et al., 2011) and the aerosol-climate model ECHAM-HAM (Zhang et al., 2012; Heinold et al., 2016). The modeling provides a perspective on the sources, transport, and the direct radiative effects of measured mineral dust and associated atmospheric feedbacks. Furthermore, ground-based in situ aerosol measurements were conducted during CADEX to investigate the relationship between the settling of mineral dust along the margin of the Central Asian mountains and the dust transport at high tropospheric levels recorded by lidar. Collection of aerosol (March 2015 to April 2016) was carried out on quartz fiber filters (MK 360, Munktell) using a high-volume filter sampler (DHA-80, DIGITEL) with an inlet for $\mathrm{PM}_{10}$ (particulate matter with a maximum diameter of $10 \mu \mathrm{m}$ ). Chemical analysis of the collected aerosol was performed with the techniques described in Fomba et al. (2014). The particle number size distribution was measured with a laser particle counter (GRIMM EDM 180) (Schettler et al., 2014). Dust dry deposition was collected (9 days in August 2016) by means of a flat-plate-type passive particle collector (Ott and Peters, 2008). Collected particles were subject to electron microscopy single particle analysis (Kandler et al., 2009, 2011), yielding information on particle size distribution, chemical and mineralogical composition, and mixing state for coarse mode particles with diameters between 0.7 and $60 \mu \mathrm{m}$. The additional model and in situ observational data, however, need further analysis and evaluation and will be used in a follow-up study.

\subsection{Lidar system}

The lidar operated in Dushanbe is a multiwavelength polarization Raman lidar Polly ${ }^{\mathrm{XT}}$ (POrtabLe Lidar sYstem Polly ${ }^{\mathrm{XT}}$, XT stands for extended version; Althausen et al., 2009) and belongs to Polly NET, a network of permanent or temporary Polly systems (Baars et al., 2016). This specific Polly ${ }^{\mathrm{XT}}$ was already deployed in numerous field campaigns in the past (e.g., Baars et al., 2012, 2016). For the CADEX campaign, this Polly ${ }^{\mathrm{XT}}$ was upgraded with a second depolarization channel at $355 \mathrm{~nm}$ wavelength (Engelmann et al., 2016). All Polly ${ }^{\mathrm{XT}}$ systems contain a laser system that emits light at 355,532 , and $1064 \mathrm{~nm}$ wavelength by means of frequency doubling and tripling. The receiver of the system has eight channels and measures the backscattered light at all three emitted wavelengths. The channels at 387, 607, and $407 \mathrm{~nm}$ wavelength allow us to detect Raman scattering at nighttime. Two other channels detect cross-polarized light at 355 and $532 \mathrm{~nm}$ wavelength. Three times a day, the system performs an automatic $\Delta 90^{\circ}$ depolarization calibration (Freudenthaler et al., 2009; Freudenthaler, 2016). Figure $2 b$ shows a sketch of the optical layout of the system. Signals are sampled with a vertical resolution of $7.5 \mathrm{~m}$ and are stored with a temporal resolution of $30 \mathrm{~s}$. Full overlap is reached at about $1.5 \mathrm{~km}$ a.g.l. (Baars et al., 2012). The resulting products of the Polly $\mathrm{XT}$ are summarized in Table 1. The corresponding uncertainties, discussed in detail in Freudenthaler et al. (2009), Baars et al. (2012, 2016), and Engelmann et al. (2016), result from uncertain input parameters and signal noise and are given as error bars in the graphs of Sect. 3. The polarization lidar photometer networking method (POLIPHON; Ansmann et al., 2011b, 2012) is applied to separate dust and non-dust optical and related microphysical properties. This separation is performed with respect to the particle backscatter coefficient (Tesche et al., 2009a; Groß et al., 2011; Mamouri and Ansmann, 2014) using the measured total particle linear depolarization ratio at $532 \mathrm{~nm}$ wavelength as well as typical particle linear depolarization ratio values (Tesche et al., 2009a; Müller et al., 2007 ) for dust (0.31) and non-dust (0.05). For the conversion of particle extinction coefficients into particle volume concentration, conversion factors for dust $\left(0.61 \times 10^{-6} \mathrm{~m}\right)$ and non-dust $\left(0.41 \times 10^{-6} \mathrm{~m}\right)$ from extended AERONET data analysis from Mamouri and Ansmann (2017) are used. Together with the densities of dust $\left(2.6 \mathrm{~g} \mathrm{~cm}^{-3}\right)$ and non-dust 


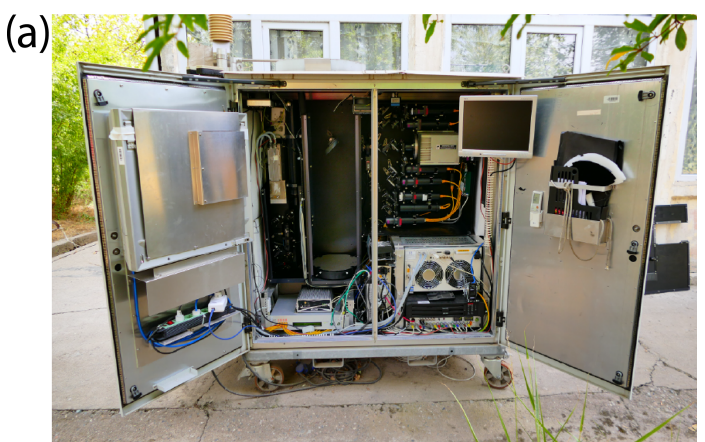

(b)

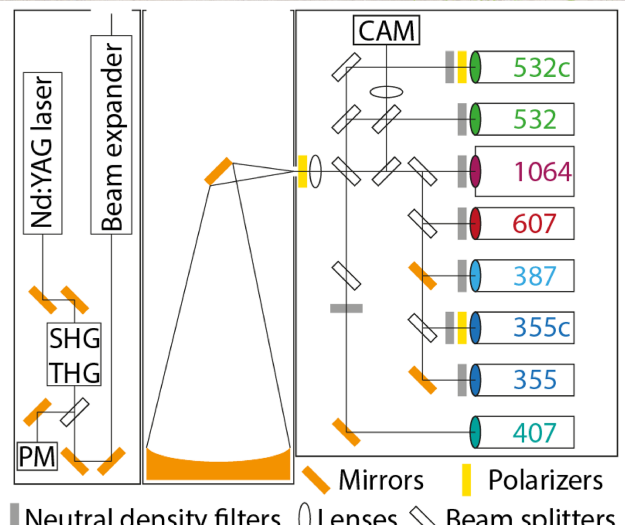

Figure 2. (a) Polly ${ }^{\mathrm{XT}}$ with closed roof, open doors, and removed protective plates at the Poligon field site in Dushanbe. The cabinet size is approximately $1.9 \mathrm{~m} \times 1.7 \mathrm{~m} \times 0.9 \mathrm{~m}$. (b) Schematic of the optical layout of the Polly XT. Left (transmitter part): after the second harmonic generation (SHG) and the third harmonic generation (THG), parts of the laser beam are deflected to a power meter (PM) which measures the UV component to monitor the conversion efficiency. Right (receiver part): backscattered light is collected with a Newtonian telescope and then passed towards the receiver unit. The numbers indicate the wavelength in nanometers of the detection channels and $\mathrm{c}$ denotes the cross-polarized channels. A camera (CAM) is synchronized to the laser trigger and sees the beam at $532 \mathrm{~nm}$ wavelength to monitor the overlap. The polarizer mounted in front of the pinhole is a device for the absolute calibration of the depolarization measurements (for details see Engelmann et al., 2016).

$\left(1.6 \mathrm{~g} \mathrm{~cm}^{-3}\right)$, this allows us to calculate dust mass concentration profiles using characteristic lidar ratio values of dust ( $40 \mathrm{sr}$ ) and non-dust $(80 \mathrm{sr})$. The uncertainty of such an estimation is given as $40 \%$ (Ansmann et al., 2011b). BravoAranda et al. (2015) compared the POLIPHON method directly to in situ aircraft measurements and found less than $30 \%$ relative difference. The measured lidar data are uploaded daily and processed automatically (Baars et al., 2016) to be displayed as "quicklooks" on the Polly ${ }^{\text {NET }}$ homepage (http://polly.rsd.tropos.de/).
Table 1. Products of the Polly XT lidar and their relative uncertainties. $\beta$ : particle backscatter coefficient, $\alpha$ : particle extinction coefficient, $S$ : lidar ratio, $\alpha_{\AA}$ : extinction-related Ångström exponent, $\delta$ : particle linear depolarization ratio, WV: water vapor, and dust and non-dust mass concentrations.

\begin{tabular}{llr}
\hline Product & Wavelengths & $\begin{array}{r}\text { Uncertainty } \\
\%\end{array}$ \\
\hline$\beta$ & $355,532,1064$ & $5-10$ \\
$\alpha$ & 355 (from 387), 532 (from 607) & $10-20$ \\
$S$ & 355,532 & $11-22$ \\
$\alpha_{\AA}$ & from $\alpha 355 / 532$ pair & $14-28$ \\
$\delta$ & 355,532 & $7-11$ \\
WV & from 407 & 20 \\
Mass conc. & from $\delta, \beta, 355,532$ & $30-50$ \\
\hline
\end{tabular}

\subsection{Auxiliary data}

Co-located with the lidar, a sun photometer as part of the AErosol RObotic NETwork (AERONET; Holben et al., 1998) was operated. The Dushanbe AERONET station (http://aeronet.gsfc.nasa.gov/cgi-bin/type_one_station opera_v2_new?site=Dushanbe) is operational since 2010 (Abdullaev et al., 2012). The Cimel sun photometer measures at eight wavelengths $(1020,870,675,500,490,440$, 380 , and $340 \mathrm{~nm}$ ) and retrieves the AOT and further columnintegrated particle optical and microphysical properties.

To calculate the Rayleigh contribution to the lidar signals in order to obtain particle optical properties, profiles of temperature and pressure are needed. Profiles of the GDAS (Global Data Assimilation System) with $1^{\circ}$ spatial resolution from the National Weather Service's National Centers for Environmental Prediction (NCEP) at the coordinates $39^{\circ} \mathrm{N}, 69^{\circ} \mathrm{E}$ were used (GDAS, 2017), because no radiosonde launches were performed in Tajikistan for several years.

Publicly available trajectory models were used to assess the possible source regions and transport routes of the dust. The HYSPLIT model (Hybrid Single Particle Lagrangian Integrated Trajectory Model; Stein et al., 2015; Rolph et al., 2017) and the FLEXPART model version 9 (FLEXible PARTicle dispersion model; Stohl et al., 2005) were run to calculate backward trajectories for the presented example cases. The $0.5^{\circ}$ GDAS meteorology for HYSPLIT and the $1^{\circ}$ GFS (Global Forecast System) meteorology for FLEXPART were used. The HYSPLIT and FLEXPART backward trajectories were calculated with a starting time approximately corresponding to the time of observation of the aerosol layer by lidar. The arrival heights above the measurement site were set to the base, center, and top of the observed layer. The FLEXPART backward trajectories were calculated for the arrival height above the measurement site in the height range of the aerosol layer measured with the lidar. The model output is the common logarithm of the accumulated residence time of 


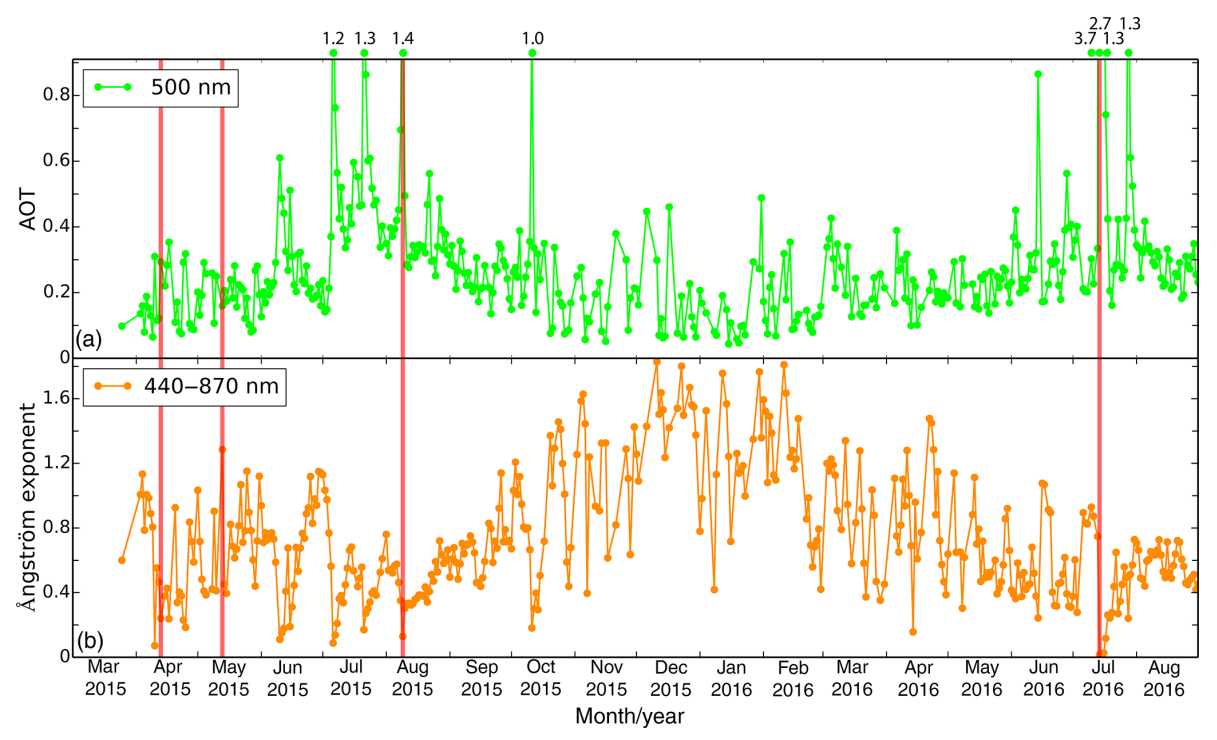

Figure 3. Daily means of the AOT (a) and Ångström exponent (b) measured in Dushanbe from March 2015 until August 2016 by sun photometer (AERONET Level 1.5, cloud-screened). The red lines indicate the days of the presented example cases.

air masses below $3 \mathrm{~km}$ during the model run time (Schwarz, 2015). This $3 \mathrm{~km}$ height is chosen because air is likely loaded with dust in the source regions, where planetary boundary layers of this magnitude occur. The spatial resolution of the model output is $1^{\circ}$.

\section{Observations}

\subsection{Overview}

An overview of the daily means of the AOT at $500 \mathrm{~nm}$ wavelength and the Ångström exponent from the 440-870 nm spectral range is shown in Fig. 3. The data were measured by sun photometer from March 2015 until August 2016 (cloudscreened AERONET data, Level 1.5). For the six 3-month seasons of the measurement campaign, the means of the AOT, the Ångström exponent, and the fine mode fraction from the $500 \mathrm{~nm}$ measurements are shown in Table 2. A seasonal transition is obvious from the winter to the summer months. The AOT increases from spring to summer and decreases again in autumn. The Ångström exponent and the fine mode fraction behave reversely. There is a dusty 6-month season from April to September, and a less dusty season from October to March, but a strong dust event still occurred in October 2015. Within these seasons, strong variations in the AOT and especially in the Ångström exponent occur from day to day. This indicates fast changes from dust-dominated to pollution-dominated aerosol conditions.

Gkikas et al. (2009, 2013, 2016) and Georgoulias et al. (2016) classified dust events in the Mediterranean region based on the long-term mean of the AOT measured by satellite and ground stations. According to this classification, a
Table 2. Seasonal means of the sun photometer measurements (AERONET Level 1.5, cloud-screened). AOT at $500 \mathrm{~nm}$ wavelength, Ångström exponent from the $440-870 \mathrm{~nm}$ spectral range, and the fine mode fraction from $500 \mathrm{~nm}$ wavelength.

\begin{tabular}{lccc}
\hline Season & AOT & $\begin{array}{c}\text { Angström } \\
\text { exponent }\end{array}$ & $\begin{array}{c}\text { Fine mode } \\
\text { fraction }\end{array}$ \\
\hline Mar-May 2015 & 0.16 & 0.63 & 0.39 \\
Jun-Aug 2015 & 0.40 & 0.54 & 0.33 \\
Sep-Nov 2015 & 0.23 & 1.03 & 0.51 \\
Dec-Feb 2015/16 & 0.15 & 1.28 & 0.71 \\
Mar-May 2016 & 0.22 & 0.82 & 0.48 \\
Jun-Aug 2016 & 0.41 & 0.52 & 0.34 \\
\hline
\end{tabular}

strong dust event equals or exceeds the mean AOT plus 2 times the standard deviation, while an extreme dust event equals or exceeds the mean AOT plus 4 times the standard deviation. This classification can be pursued for the station in Dushanbe with AERONET data (Level 2.0), which are available from July 2010 to November 2016 (1413 days). The mean of the daily mean AOT at $500 \mathrm{~nm}$ wavelength is 0.28 with a standard deviation of 0.23 . As a comparison, Georgoulias et al. (2016) found a long-term mean AOT at $550 \mathrm{~nm}$ wavelength of $0.22 \pm 0.19$ for the Eastern Mediterranean region. So in Dushanbe, days with an AOT $\geqslant 0.74$ are therefore strong dust events, while days with an AOT $\geqslant 1.2$ at $500 \mathrm{~nm}$ wavelength are extreme dust events. Considering only the measurement period from March 2015 to August 2016, the mean AOT at $500 \mathrm{~nm}$ wavelength was 0.28 (with a standard deviation of 0.16 ) and therefore equal to the longterm mean. According to this classification, six episodes of strong dust and six episodes of extreme dust occurred during 

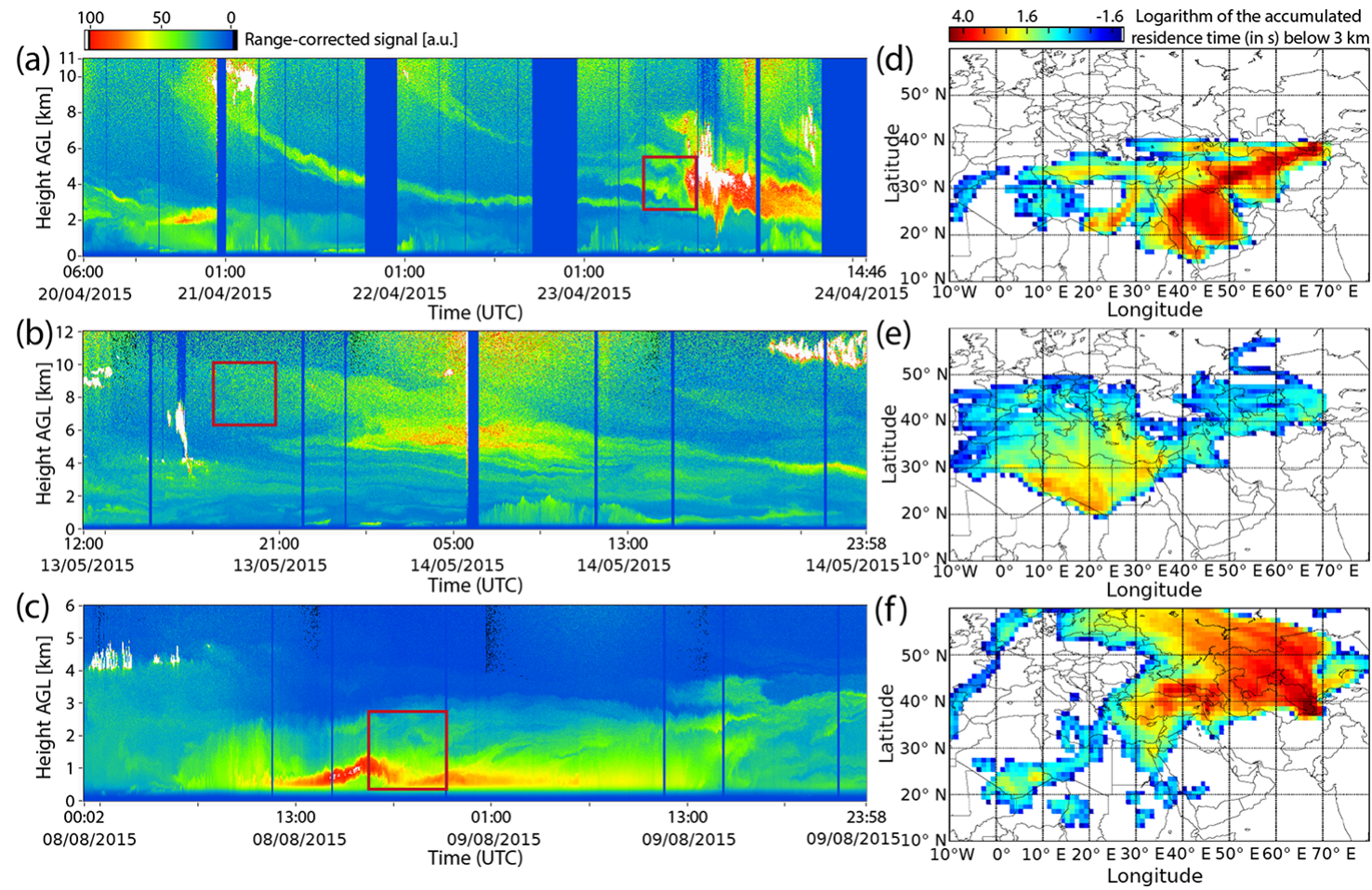

Figure 4. (a, b, c) Illustrative measurement examples of aerosol layers observed with Polly $\mathrm{XT}$ at Dushanbe, partly up to the cirrus level $(10 \mathrm{~km}$ height). Temporal development of the range-corrected signal (temporal resolution $30 \mathrm{~s}$, vertical resolution $7.5 \mathrm{~m}$ ) of the $1064 \mathrm{~nm}$ wavelength channel on (a) 20 April 2015, 06:00 UTC - 24 April 2015, 14:46 UTC. (b) 13 May 2015, 12:00 UTC - 14 May 2015, 23:58 UTC. (c) 8 August 2015, 00:02 UTC - 9 August 2015, 23:58 UTC. Blue rectangles denote periods where no measurements were performed. (d, e, f) Source regions of the observed aerosol identified based on FLEXPART model runs. The first lofted layer (a) has Middle Eastern sources (d), the second lofted layer (b) has North African sources (e) and the third low laying dust (c) has Central Asian sources (f). The dark red squares in the left panels indicate the arrival height and time of the calculated backward trajectories in the context of the lidar measurements. The right panels show maps of the logarithm of accumulated residence time below $3 \mathrm{~km}$ (in seconds) of $144 \mathrm{~h}$ FLEXPART backward trajectories arriving above Dushanbe on (d) 23 April 2015, 20:30-21:30 UTC between 2.7 and $5 \mathrm{~km}$, (e) 13 May 2015, 17:30-18:30 UTC between 6.6 and $9.9 \mathrm{~km}$ height, and (f) 8 August 2015, 21:30-22:30 UTC between 0.5 and $3.1 \mathrm{~km}$ height.

the measurement period. In the period July 2010 to November 2016 (6.25 years), strong dust events occurred 19 times ( 3 per year), extreme dust events 10 times (1.6 per year), and more than extreme dust events with an AOT above 2 at $500 \mathrm{~nm}$ wavelength occurred 4 times ( 0.6 per year).

\subsection{Illustrative measurement examples}

To illustrate the frequently observed variety and complexity of dust layers above Tajikistan, examples of dust layers of various origins occurring at all heights from the surface to the cirrus level are presented in Fig. 4. Figure 4a shows the temporal development of the range-corrected signal of the $1064 \mathrm{~nm}$ wavelength channel from 20 to 24 April 2015. During these 4 days, multiple dust layers arrived above Tajikistan. On 20 April 2015 there were aerosol layers up to $4 \mathrm{~km}$ height. At the same time, descending dust layers crossed the lidar station at heights of about $10 \mathrm{~km}$. On 22 April $2015 \mathrm{a}$ second dust layer arrived at $10 \mathrm{~km}$ height, which again descended. According to FLEXPART trajectories, the Arabian
Peninsula, Iran, and parts of Uzbekistan and Turkmenistan were also source regions for the detected dust (Fig. 4d). A high-altitude aerosol layer was measured on 13 May 2015, reaching roughly from 6.5 to $10 \mathrm{~km}$ altitude (Fig. 4b). FLEXPART back-trajectory analysis shows that this high layer was long-range transported towards the measurement site from the Mediterranean and North African region (Fig. 4e). The third scenario is a near-ground dust layer (Fig. 4c; described in detail in Sect. 3.3.2), which was measured on 8 and $9 \mathrm{Au}-$ gust 2015 and had Central Asian sources (Fig. 4f).

\subsection{Case studies}

In the following sections we discuss four strongly contrasting cases in more detail: (1) A lofted layer of Middle Eastern dust that occurred on 13 April 2015 (Case 1; Fig. 5; Sect. 3.3.1); (2) an extreme dust event with Central Asian dust, which was recorded on 8 and 9 August 2015 (Case 2; Fig. 6; Sect. 3.3.2); (3) the most extreme dust event during the CADEX campaign with dust from Central Asian sources, which was ob- 

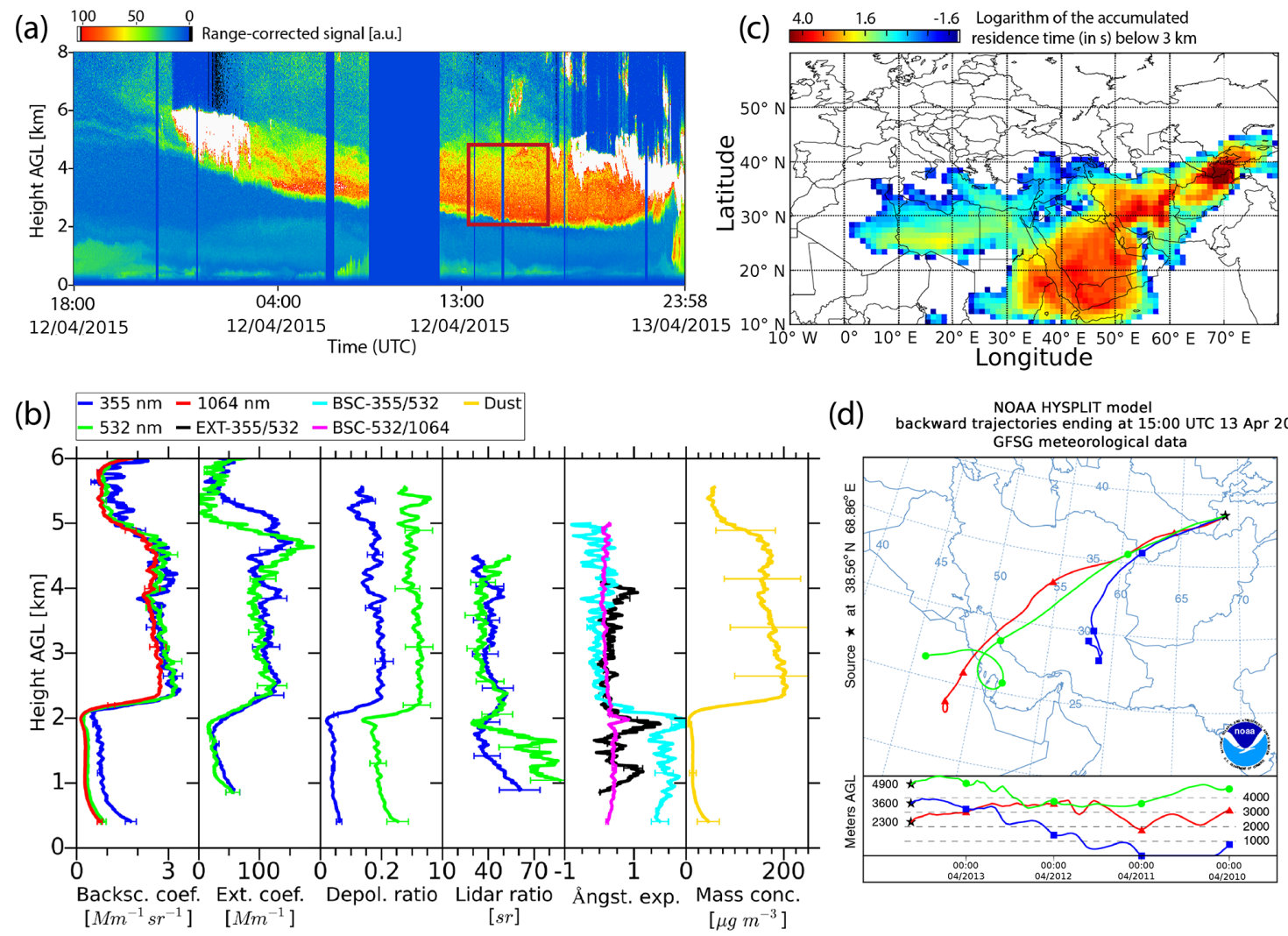

NOAA HYSPLIT model
(d) backward trajectories ending at 15:00 UTC 13 Apr 2015 GFSG meteorological data

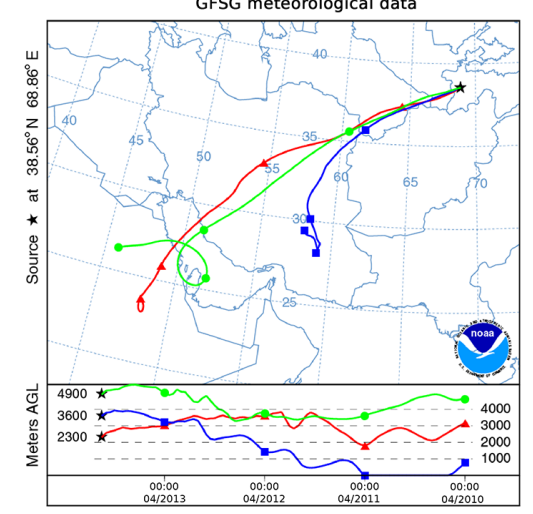

$\left[\mu \mathrm{g} \mathrm{m}^{-3}\right]$

Figure 5. Case 1: a lofted layer of Middle Eastern dust is shown. (a) Same as Fig. 4a, b, c, but on 12 April 2015, 18:00 UTC - 13 April 2015, 23:58 UTC. (b) The averaged lidar profiles were measured on 13 April 2015, 15:10-16:08 UTC. Lidar signals are smoothed before calculation of the extinction-related $(743 \mathrm{~m})$ and backscatter-related $(68 \mathrm{~m})$ optical properties. Particle backscatter coefficient at 355, 532, and 1064 nm wavelength are shown. Particle extinction coefficient, particle linear depolarization ratio, and lidar ratio at 355 and $532 \mathrm{~nm}$ wavelength are also shown. Extinction-related Ångström exponent from 355 and $532 \mathrm{~nm}$ wavelengths (black), backscatter-related Ångström exponent from 355 and $532 \mathrm{~nm}$ wavelengths (cyan), and backscatter-related Ångström exponent from 532 and 1064 nm wavelengths (magenta). Dust mass concentration are shown in yellow. (c) $144 \mathrm{~h}$ FLEXPART backward trajectories same as in Fig. 4d, e, f, but arriving on 13 April 2015 , 14:30-15:30 UTC between 2.3 and $4.9 \mathrm{~km}$ height. (d) $96 \mathrm{~h}$ HYSPLIT backward trajectories arriving at Dushanbe at 18:00 UTC at 2.3, 3.6, and $4.9 \mathrm{~km}$ height.

served on 14 July 2016 (Case 3; Fig. 7; Sect. 3.3.3); and (4) a contrasting case with a pollution layer of local origin, which was measured on 13 May 2015 (Case 4; Fig. 8; Sect. 3.3.4).

\subsubsection{Case 1: 13 April 2015, lofted dust layer}

Figure 5a shows the temporal development of the rangecorrected signal of the $1064 \mathrm{~nm}$ wavelength channel on 12 13 April 2015. The dust layer arrived over Dushanbe on 12 April 2015 at an altitude between 5 and $6 \mathrm{~km}$. The slowly descending dust layer (red) contained dense clouds (white). On 13 April 2015 the dust layer extended at about $2.5-5 \mathrm{~km}$ height. Its base was very sharp while on top of the layer a thinner aerosol layer was measured up to $7 \mathrm{~km}$. At the end of that day, a down-mixing of dust into the lowermost $2 \mathrm{~km}$ occurred. The HYSPLIT backward trajectories arriving on 13 April 2015 show that the air parcels are coming from a southwestern direction (Fig. 5d). The upper and the lower trajectories come from the Arabian Peninsula and travel over central Iran and along the Afghanistan-Turkmenistan border. The upper trajectory is always more than $3 \mathrm{~km}$ above ground, while the lower trajectory reached below $2 \mathrm{~km}$ once above the Arabian Peninsula. The center trajectory is coming from a more southern direction, traveling over southern Iran, where it reaches down to below $1 \mathrm{~km}$ above the Iranian Dasht-e Lut desert.

Similar to HYSPLIT, the FLEXPART backward trajectories indicate Iran including its southern parts and large parts of the Arabian Peninsula as source regions (Fig. 5c). In contrast to HYSPLIT, the FLEXPART backward trajectories resided partly above Afghanistan.

Vertical profiles of the optical properties of this dust layer are shown in Fig. 5b. The particle linear depolarization ratio at $532 \mathrm{~nm}$ wavelength is on average 0.31 and 0.34 at its maximum. This shows that this lofted dust layer consists of almost unpolluted dust. Depolarization ratios of pure Mid- 


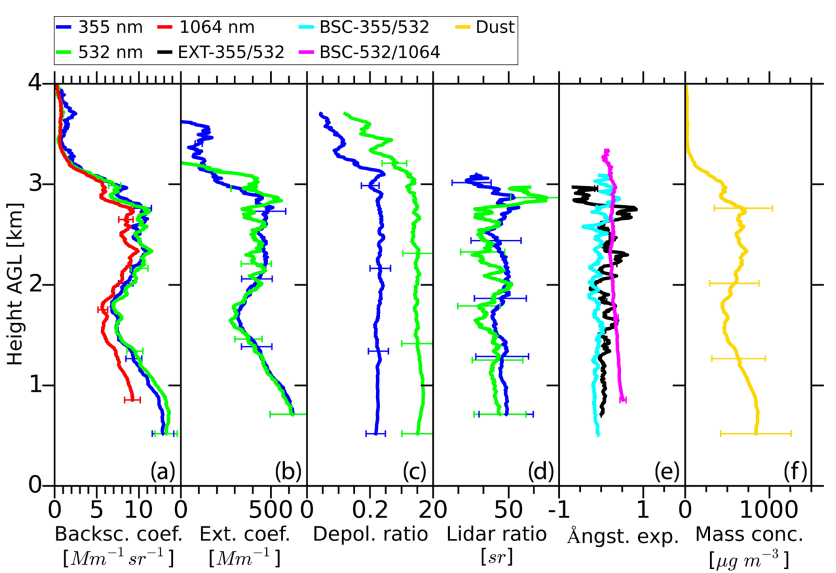

Figure 6. Case 2: an extreme dust layer with an AOT of 1.5 (at $532 \mathrm{~nm}$ wavelength) and a calculated dust mass concentration of $845 \mu \mathrm{g} \mathrm{m}^{-3}$ is shown. The source regions of this dust are in Central Asia (Fig. 4f). (a-f) Same as Fig. 5b. The averaged lidar profiles were measured on 8 August 2015, 22:20-23:57 UTC. Lidar signals are smoothed before calculation of the extinction-related $(458 \mathrm{~m})$ and backscatter-related $(68 \mathrm{~m})$ optical properties.

dle Eastern dust close to its source regions have been found as $0.3-0.35$ at $532 \mathrm{~nm}$ wavelength (Mamouri et al., 2013, 2016). The mean lidar ratio is $35.7 \pm 1.7 \mathrm{sr}$ at $532 \mathrm{~nm}$ wavelength, which is comparable to measurements for Middle Eastern dust (Mamouri et al., 2013; Nisantzi et al., 2015). The lofted dust layer has a maximum dust mass concentration of $196 \mu \mathrm{g} \mathrm{m}^{-3}$ at the bottom of the layer at $2.7 \mathrm{~km}$. In the middle of the layer at $3.5 \mathrm{~km}$ the dust mass concentration reaches $171 \mu \mathrm{g} \mathrm{m}^{-3}$. The integrated dust mass up to $5 \mathrm{~km}$ altitude is $0.51 \mathrm{~g} \mathrm{~m}^{-2}$. The non-dust components in this layer are negligible, except in the upper parts of the layer, where the particle linear depolarization ratio partly drops below 0.31 at $532 \mathrm{~nm}$ wavelength.

\subsubsection{Case 2: 8 and 9 August 2015, extreme dust event}

An extreme dust event was measured on 8 and 9 August 2015. Figure $4 \mathrm{c}$ shows the temporal development of the range-corrected signal of the $1064 \mathrm{~nm}$ wavelength channel on 8-9 August 2015. The dust got lifted up with the evolution of the convective boundary layer. This led to a very strong signal in the lowest $1.5 \mathrm{~km}$ with dust extending up to about $3 \mathrm{~km}$ height.

The FLEXPART trajectories arriving on 8 August 2015 (Fig. 4f) exhibit a large area northwest of Tajikistan with high accumulated residence times, even west of the Caspian Sea.

Vertical profiles of the optical properties of this dust layer are shown in Fig. 6. The particle extinction coefficients at 355 and $532 \mathrm{~nm}$ wavelength are about $550 \mathrm{Mm}^{-1}$ at $1 \mathrm{~km}$ height. Apparently, the layer is divided in two parts. There is a maximum in the first $1 \mathrm{~km}$ above ground and then again at about $2.5 \mathrm{~km}$ height. However, looking at the intensive prop-
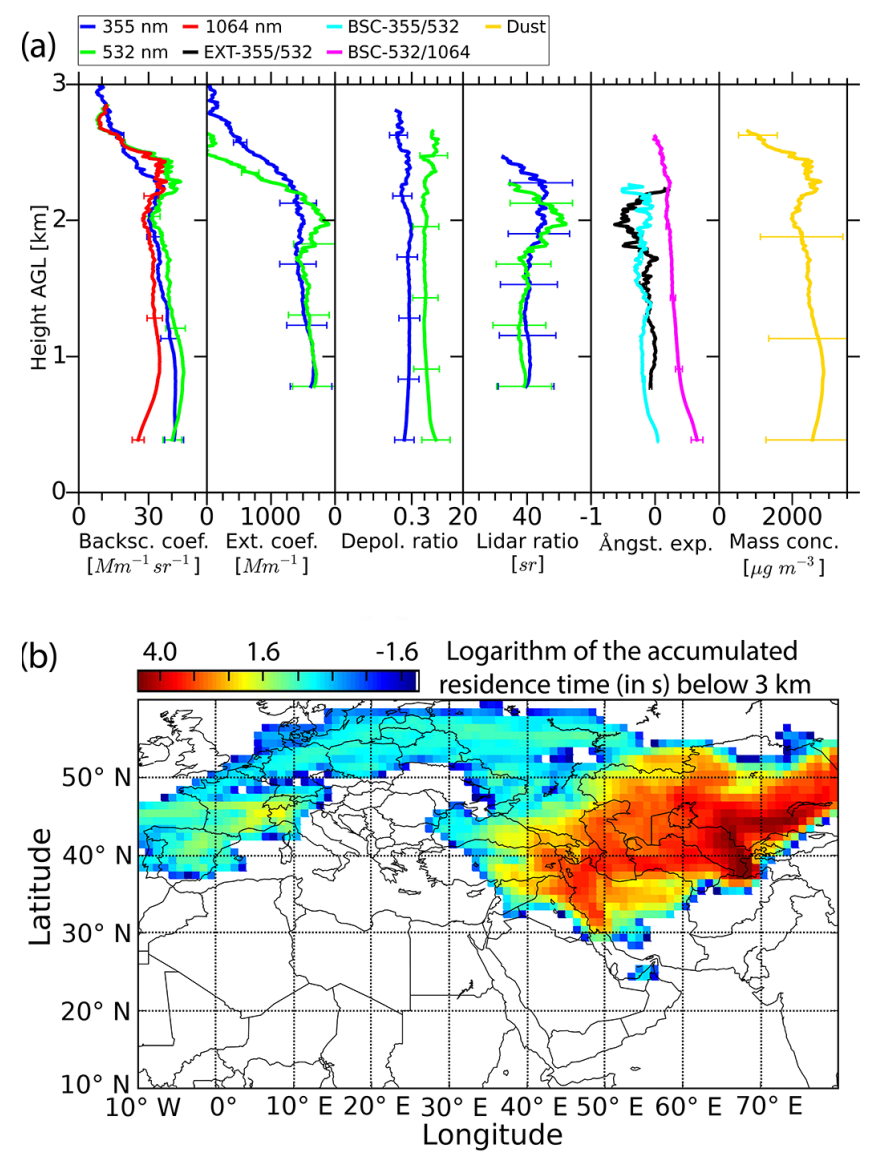

(c)

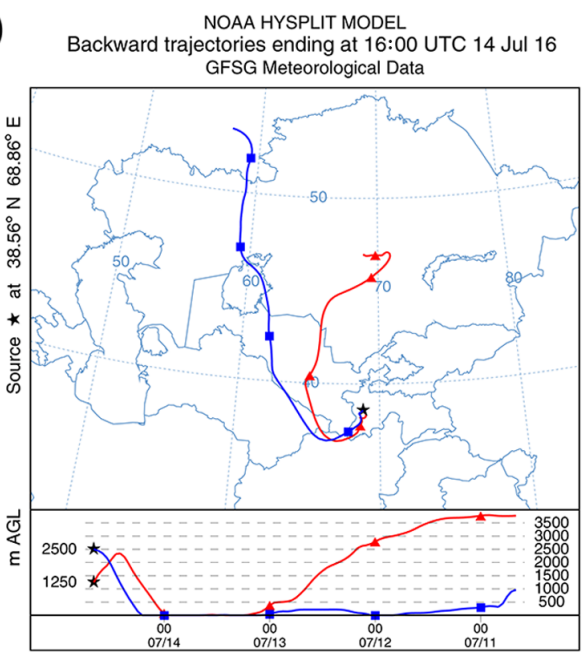

Figure 7. Case 3: the most extreme dust event with an AOT of above 4 (at $500 \mathrm{~nm}$ wavelength) and a calculated dust mass concentration of $2.8 \mathrm{mg} \mathrm{m}^{-3}$ is shown. The dust source regions are in Central Asia. (a) Same as Fig. 5b. The averaged lidar profiles were measured on 14 July 2016, 16:00-22:00 UTC. Lidar signals are smoothed before calculation of the extinction-related $(743 \mathrm{~m})$ and backscatter-related (248 m) optical properties. (b) $120 \mathrm{~h}$ FLEXPART backward trajectories same as in Fig. 4d, e, f, but arriving on 14 July 2016, 20:30-21:30 UTC between 0.5 and $2.6 \mathrm{~km}$ height. (c) $96 \mathrm{~h}$ HYSPLIT backward trajectories arriving at Dushanbe at 16:00 UTC at 1.25 , and $2.5 \mathrm{~km}$ height. 


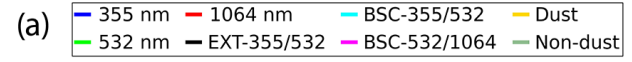

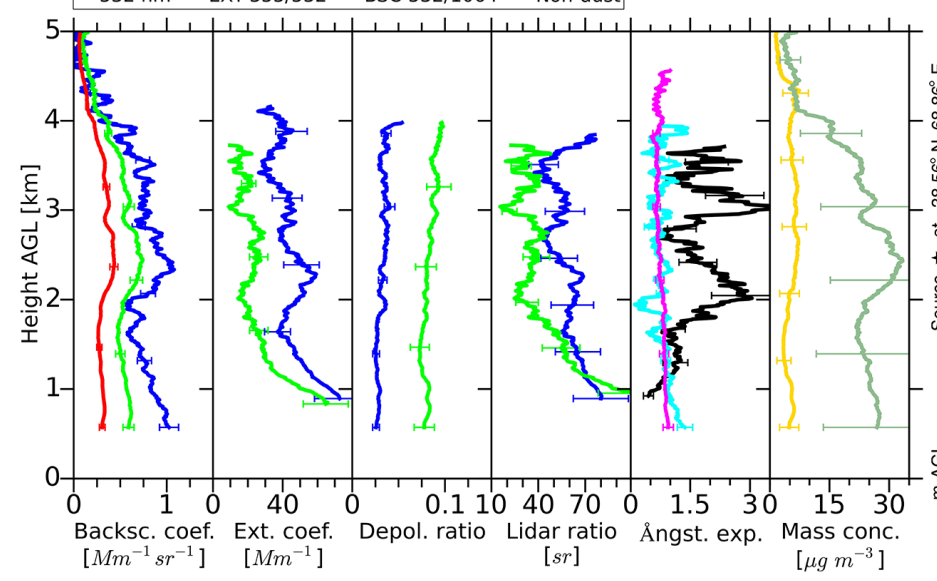

(b) NOAA HYSPLIT model

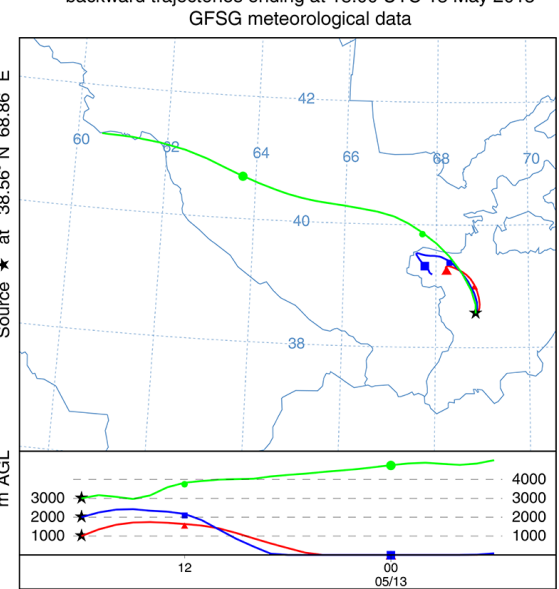

Figure 8. Case 4: a contrasting case with local pollution is shown. (a) Same as Fig. 5b. Averaged lidar profiles measured on 13 May 2015 , 18:10-20:30 UTC. Lidar signals are smoothed before calculation of the extinction-related (788 $\mathrm{m})$ and backscatter-related (98 $\mathrm{m})$ optical properties. (b) $48 \mathrm{~h}$ HYSPLIT backward trajectories arriving at Dushanbe at 18:00 UTC at 1, 2, and $3 \mathrm{~km}$ height.

erties, especially the particle linear depolarization ratio and the extinction-related Ångström exponent, continuous features are recognizable. The twofold layer probably contains the same aerosol and originates from the same source region since it has almost identical optical properties. The apparent layer boundary at $1.6 \mathrm{~km}$ is probably formed by the diurnal cycle of the boundary layer. The development of the convective boundary layer after about 06:00 UTC on 8 August 2015 is visible in Fig. 4c. The mean particle linear depolarization ratios are higher than in the lofted dust layer before (Case 1), on average 0.35 at $532 \mathrm{~nm}$ wavelength. The maximum dust mass concentration of that extreme near-ground dust layer is $845 \mu \mathrm{g} \mathrm{m}^{-3}$ at $0.65 \mathrm{~km}$ height, in the middle of the layer the minimum is $475 \mu \mathrm{g} \mathrm{m}^{-3}$ at $1.7 \mathrm{~km}$. In the upper part at $2.4 \mathrm{~km}$ the dust mass concentration is again $663 \mu \mathrm{g} \mathrm{m}{ }^{-3}$. The integrated dust mass up to $4 \mathrm{~km}$ altitude is $3.2 \mathrm{~g} \mathrm{~m}^{-2}$.

\subsubsection{Case 3: 14 July 2016, most extreme dust event}

The most extreme dust event during the CADEX campaign occurred on 14 July 2016. The dust persisted during the next 4 days (Fig. 3). The FLEXPART trajectories arriving on 14 July 2016 (Fig. 7b) show large accumulated residence times as far away as western Iran, but the highest values are in Uzbekistan. The accumulated residence times above Kazakhstan are high, but they are also reaching eastwards towards Lake Balkhash, differently than on 8 August 2015 (Fig. 4f). The HYSPLIT backward trajectories arriving on 14 July 2016 are shown in Fig. 7c. The higher trajectory arrived from the Aral Sea and the lower one from central Kazakhstan through Turkmenistan and Afghanistan. The vertical profiles of the measured optical properties of this dust layer are presented in Fig. 7a. The particle extinction coefficients at 355 and $532 \mathrm{~nm}$ wavelength are about $1.7 \mathrm{~km}^{-1}$ at $1 \mathrm{~km}$ height. The resulting AOT is 3.89 at $532 \mathrm{~nm}$ wavelength, which is much higher than the long-term mean plus 10 times the standard deviation (see Sect. 3.1). The 14 July 2016 has the highest daily mean AOT since the beginning of the record in Dushanbe with the AERONET sun photometer in 2010. Therefore, this dust event could well be called recordbreaking similar to how Mamouri et al. (2016) called an extreme dust event in September 2015 in the Mediterranean. The mean particle linear depolarization ratio at $355 \mathrm{~nm}$ wavelength is 0.29 and thus higher than in Case 2, while at $532 \mathrm{~nm}$ wavelength it is equally 0.35 . The calculated dust mass concentrations for that most extreme dust is largest at $1 \mathrm{~km}$ altitude with $2.8 \mathrm{mg} \mathrm{m}^{-3}$. The integrated dust mass up to $2.7 \mathrm{~km}$ altitude is $6.5 \mathrm{~g} \mathrm{~m}^{-2}$.

\subsubsection{Case 4: 13 May 2015, contrasting case with local pollution}

Figure $4 \mathrm{~b}$ shows the temporal development of the rangecorrected signal of the $1064 \mathrm{~nm}$ wavelength channel on 1314 May 2015. There were several aerosol layers distributed up to $10 \mathrm{~km}$ height. The HYSPLIT backward trajectories arriving on 13 May 2015 are shown in Fig. 8b. The upper trajectory is coming from northwest of Tajikistan and the lower trajectories reach down to the ground the same day inside Tajikistan, indicating the contribution of local pollution to the lower altitude aerosol layers.

The vertical profiles of the measured optical properties are presented in Fig. 8a. The particle extinction coefficients in the layer at about $2-4 \mathrm{~km}$ are about $40 \mathrm{Mm}^{-1}$ at $355 \mathrm{~nm}$ and $20 \mathrm{Mm}^{-1}$ at $532 \mathrm{~nm}$ wavelength. This aerosol layer is barely depolarizing and the mean extinction-related Ångström exponent is $2.07 \pm 0.72$. The dust mass concentration reaches $6.9 \mu \mathrm{g} \mathrm{m}^{-3}$ at $2.5 \mathrm{~km}$ height, the non-dust mass concentration 
is at the same time dominating with $30.7 \mu \mathrm{g} \mathrm{m}^{-3}$. The integrated dust mass up to $10.4 \mathrm{~km}$ altitude is $0.05 \mathrm{~g} \mathrm{~m}^{-2}$ and the integrated non-dust mass is $0.13 \mathrm{~g} \mathrm{~m}^{-2}$. Finally, an overview of the individual cases is given in Table 3 , where the intensive optical properties and AOTs of the presented example cases are summarized.

\section{Discussion}

Four exemplary measurement cases are described in this article. Two of them are from spring and one is from summer 2015 and one is from summer 2016. In early spring, the AOT was predominantly low ( $\leq 0.3$; Fig. 3 ) but a lot of dust layers occurred, e.g., 13 April 2015 (Case 1; Fig. 5) and 20-24 April 2015 (Fig. 4a). In summer, the AOT in general was higher $(\geq 0.35)$ and some dust events overtopped that clearly, e.g., 8-9 August 2015 (Case 2; Fig. 6) and 14 July 2016 (Case 3; Fig. 7). However, a statistical analysis of the lidar profiles of the whole measurement period has yet to follow.

\subsection{Dust AOT and mass concentration}

The lofted dust layer in Case 1 contributed significantly to the total AOT of about 0.4 at $532 \mathrm{~nm}$ wavelength. Case 2 had an AOT of 1.5 at $532 \mathrm{~nm}$ wavelength. The most extreme dust case during the measurement campaign was Case 3 with an extraordinary AOT of above 3.5 at $532 \mathrm{~nm}$ wavelength as measured by lidar and above 4 as measured by sun photometer. The AOT of Case 2 is comparable to a dust event during the Soviet-American campaign in 1989 (AOT of 1.3 at $550 \mathrm{~nm}$ wavelength; Gomes and Gillette, 1993). The most extreme dust event (Case 3) is comparable to the second dust event during the Soviet-American campaign (AOT of 3.3 at $550 \mathrm{~nm}$ wavelength; Pachenko et al., 1993). Pachenko et al. (1993) estimated the maximum AOT of that dust event a day before was greater than 10 , based on horizontal visibility, which was reported to be 50-200 m (Smirnov et al., 1994). As a comparison, Mamouri et al. (2016) reported a visibility of 500-600 $\mathrm{m}$ for an extraordinary dust event in the Mediterranean area, inferring an AOT of 4.8 to 9 depending on the layer height. This again led to an estimate of the column dust load of $8-15 \mathrm{~g} \mathrm{~m}^{-2}$. These values are higher than for Case 3, where the AOT was 3.89 at $532 \mathrm{~nm}$ wavelength, and the integrated dust mass was $6.7 \mathrm{~g} \mathrm{~m}^{-2}$. The visibility calculated from the measured particle extinction coefficient of $1.7 \mathrm{~km}^{-1}$ (measured at $0.87 \mathrm{~km}$ altitude) was $2.3 \mathrm{~km}$. The AOT and the dust mass concentrations for this Case 3 were calculated based on the lidar data only, but the sun photometer measured an even higher AOT of 4.45 at $500 \mathrm{~nm}$ wavelength.

\subsection{Dust layer height}

The multiple high-altitude dust layers preceding the lofted dust layer on 24 April 2015 (Fig. 4a) and the high aerosol layer on 13 May 2015 (Fig. 4b) reached heights of about $10 \mathrm{~km}$ a.g.l. This is higher than the highest point of the Pamir mountains (7.6 kma.s.1.), which means that these layers can cross the Pamir or the Tien Shan mountains (7.4 kma.s.1.) and can be transported further eastwards. A similar observation was made in spring 2003 when layers of elevated depolarization at $9-11 \mathrm{~km}$ height have been measured by lidar in Aksu (northwestern Taklamakan; Mikami et al., 2006). Within a week time, lidar stations in Japan measured dust at altitudes between 2 and $6 \mathrm{~km}$, without having major dust outbreaks in the Taklamakan and Gobi deserts. Model simulations indicated that the dust was transported to Japan via north of the Tien Shan mountains (Tanaka et al., 2005). For that case, Tanaka et al. (2005) estimated $50 \%$ of the dust particles arriving in Japan came from the Sahara, $30 \%$ from the Middle East, and only $10 \%$ from China.

\subsection{Lidar ratio and dust source region}

The observed lidar ratios in the presented dust cases (Cases 1, $2,3)$ range from 40.3 to $46.9 \mathrm{sr}$ at $355 \mathrm{~nm}$ and from 35.7 to $42.9 \mathrm{sr}$ at $532 \mathrm{~nm}$ wavelength. The lofted dust layer (Case 1) has lidar ratios of $42.2 \mathrm{sr}$ at $355 \mathrm{~nm}$ and $35.7 \mathrm{sr}$ at $532 \mathrm{~nm}$ wavelength. The near-ground dust layers (Cases 2, 3) have lidar ratios of 46.9 and $40.3 \mathrm{sr}$ at $355 \mathrm{~nm}$ and 42.9 and $38.7 \mathrm{sr}$ at $532 \mathrm{~nm}$ wavelength. The only weakly depolarizing pollution aerosol in Case 4 has lidar ratios of $55.8 \mathrm{sr}$ at $355 \mathrm{~nm}$ and $32.8 \mathrm{sr}$ at $532 \mathrm{~nm}$ wavelength, but with high variability.

Saharan dust is found to have lidar ratios of 50-60 sr at $532 \mathrm{~nm}$ wavelength (e.g., Groß et al., 2015; Tesche et al., 2009b). Schuster et al. (2012) used AERONET data sets to retrieve pure dust lidar ratios and found lower values for west-Asian dust than for North African dust. Similar results were found from Raman lidar measurements in Cyprus with lidar ratios of 35-45 sr for Middle Eastern dust (Mamouri et al., 2013; Nisantzi et al., 2015). In east Asia, lidar ratios of Asian dust of, for example, $47 \pm 18 \mathrm{sr}$ (Sakai et al., 2003) and $42-73 \mathrm{sr}$ (Liu et al., 2002) at $532 \mathrm{~nm}$ wavelength were reported. In China, lidar ratios of $40 \pm 5 \mathrm{sr}$ (Tesche et al., 2007) and $35 \pm 5 \mathrm{sr}$ (Müller et al., 2007) at $532 \mathrm{~nm}$ wavelength for dust from the Gobi desert were measured. The situation in Central Asia is even more unclear, as almost no measurements exist. Although direct measurements of dust lidar ratios inside of the Taklakaman are not yet available, Jin et al. (2010) used constrains to retrieve a dust lidar ratio of $42 \pm 3 \mathrm{sr}$ at $532 \mathrm{~nm}$ wavelength in Aksu (northwestern Taklamakan). Chen et al. (2013) measured very low lidar ratios of 8-29 sr at $532 \mathrm{~nm}$ wavelength in weakly depolarizing dust layers in Kyrgyzstan. For dust from the Caspian and Aral sea region, a lidar ratio of $43 \pm 3 \mathrm{sr}$ at $532 \mathrm{~nm}$ was measured (Dieudonné et al., 2015).

The lidar ratios of the example dust cases (Cases 1, 2, 3 ) agree well with these values. There is no clear difference between the lofted dust layer (Case 1), which is longrange transported Middle Eastern dust and the near-ground 
Table 3. Overview of the selected example cases. $S_{355}, S_{532}$ : lidar ratios at 355 and $532 \mathrm{~nm}$ wavelength. $\delta_{355}, \delta_{532}$ : particle linear depolarization ratios at 355 and $532 \mathrm{~nm}$ wavelength. $\tau_{\text {lidar }}$ : aerosol optical thickness measured with lidar at $532 \mathrm{~nm}$ wavelength. $\tau_{\text {SPM }}$ : aerosol optical thickness measurement of the co-located sun photometer at $500 \mathrm{~nm}$ wavelength (time of measurements in the footnote). $\alpha_{\AA} 355 / 532$ : extinction-related Ångström exponent based on the particle extinction coefficients at 355 and 532 nm wavelength. $\beta_{\AA 355 / 532}, \beta_{\AA 532 / 1064}$ : backscatter-related Ångström exponents based on the particle backscatter coefficients at 355, 532, and $1064 \mathrm{~nm}$ wavelength. The height range to average the optical properties of the dust layers is placed within the core of each layer. The provided uncertainties are the standard deviations of the averaged values.

\begin{tabular}{lrrrr}
\hline Case & $\begin{array}{r}\text { Case 1 } \\
\text { lofted dust }\end{array}$ & $\begin{array}{r}\text { Case 2 } \\
\text { extreme dust }\end{array}$ & $\begin{array}{r}\text { Case 3 } \\
\text { most extreme dust }\end{array}$ & $\begin{array}{r}\text { Case 4 } \\
\text { pollution }\end{array}$ \\
\hline Source region & Middle East & Central Asia & Central Asia & local \\
Date & 13 Apr 2015 & 8 Aug 2015 & 14 Jul 2016 & 13 May 2015 \\
UTC time & $15: 10-16: 09$ & $22: 20-23: 57$ & $16: 00-21: 59$ & $18: 10-22: 00$ \\
Layer height (km a.g.1.) & $2.3-4.9$ & $0-3.1$ & $0-2.6$ & $0-4.1$ \\
$S_{355}$ (sr) & $42.2 \pm 3.0$ & $46.9 \pm 2.1$ & $40.3 \pm 0.6$ & $55.8 \pm 7.1$ \\
$S_{532}(\mathrm{sr})$ & $35.7 \pm 1.7$ & $42.9 \pm 3.2$ & $38.7 \pm 1.0$ & $32.8 \pm 6.4$ \\
$\delta_{355}$ & $0.18 \pm 0.02$ & $0.23 \pm 0.01$ & $0.29 \pm 0.01$ & $0.03 \pm 0.01$ \\
$\delta_{532}$ & $0.31 \pm 0.01$ & $0.35 \pm 0.01$ & $0.35 \pm 0.01$ & $0.08 \pm 0.01$ \\
$\tau_{\text {lidar }}$ & $0.40(0-5.4 \mathrm{~km})$ & $1.50(0-4.1 \mathrm{~km})$ & $3.89(0-3 \mathrm{~km})$ & $0.13(0-4.5 \mathrm{~km})$ \\
$\tau_{\mathrm{SPM}}$ & $0.41^{1}$ & $1.19^{2}, 1.69^{3}$ & $4.45^{4}, 2.89^{5}$ & $0.18^{6}$ \\
$\alpha_{\AA 355 / 532}$ & $0.41 \pm 0.24$ & $0.12 \pm 0.16$ & $-0.08 \pm 0.06$ & $2.07 \pm 0.72$ \\
$\beta_{\AA 355 / 532}$ & $0.00 \pm 0.22$ & $-0.11 \pm 0.09$ & $-0.20 \pm 0.13$ & $0.72 \pm 0.16$ \\
$\beta_{\AA 532 / 1064}$ & $0.12 \pm 0.04$ & $0.32 \pm 0.07$ & $0.29 \pm 0.03$ & $0.71 \pm 0.05$ \\
\hline
\end{tabular}

UTC times of sun photometer measurements: ${ }^{1} 13$ April 2015, 12:54:46, ${ }^{2} 8$ August 2015, 13:04:24, ${ }^{3} 9$ August 2015, 02:08:05, ${ }^{4} 14$ July 2016, 09:16:02, ${ }^{5} 15$ July 2016, 03:29:3, and ${ }^{6} 13$ May 2015, 13:21:50.

fresh dust layers (Cases 2, 3) from Central Asian sources. The lofted dust layer in Case 1 has a very low lidar ratio of $35.7 \pm 1.7$ at $532 \mathrm{~nm}$ wavelength, indeed comparable to the ones ( $33.7 \pm 6.7$ to $39.1 \pm 5.1 \mathrm{sr}$ at $532 \mathrm{~nm})$ found by Mamouri et al. (2013) for dust from the Middle East. However, the most extreme dust event (Case 3) also has a lidar ratio below $40 \mathrm{sr}$ at $532 \mathrm{~nm}$ wavelength. Then again, slightly larger lidar ratios above $40 \mathrm{sr}$ were measured in the extreme near-ground dust layer (Case 2). The lidar ratios of the pollution layer (Case 4) differ significantly between the two wavelengths.

\subsection{Dust particle linear depolarization ratio}

The observed depolarization ratios in the presented dust cases (Cases 1, 2,3) range from 0.18 to 0.29 at $355 \mathrm{~nm}$ and from 0.31 to 0.35 at $532 \mathrm{~nm}$ wavelength. The lofted dust layer (Case 1) has a depolarization ratio of 0.18 at $355 \mathrm{~nm}$ and 0.31 at $532 \mathrm{~nm}$ wavelength. The two near-ground dust cases (Cases 2,3) have depolarization ratios of 0.23 and 0.29 at $355 \mathrm{~nm}$ and both are 0.35 at $532 \mathrm{~nm}$ wavelength. In contrast to the dust cases, the local pollution aerosol (Case 4) has low depolarization ratios of 0.03 at $355 \mathrm{~nm}$ and 0.08 at $532 \mathrm{~nm}$ wavelength.

Dieudonné et al. (2015) measured a particle linear depolarization ratio of $0.23 \pm 0.02$ at $532 \mathrm{~nm}$ wavelength for lofted dust from the Caspian and Aral sea region. From the Kyrgyzstan station depolarization ratio values of $0.1-0.15$ for lofted dust layers (Chen et al., 2013) and around 0.2 at $532 \mathrm{~nm}$ wavelength for near-ground dust layers were reported (Chen and Sverdlik, 2007). However, it has to be considered that this station is already located at $1.9 \mathrm{~km}$ a.s.l. In Aksu (northwestern Taklamakan), Kai et al. (2008) measured depolarization ratios at $532 \mathrm{~nm}$ wavelength of $0.09^{*}-0.11^{*}$ in a lofted dust layer and $0.18^{*}-0.33^{*}$ in a near-ground dust layer. Iwasaka et al. (2003) measured a depolarization ratio of $0.27^{*}$ at $532 \mathrm{~nm}$ wavelength in a lofted dust layer in Dunhuang (northern Taklamakan). Note that the values denoted with * are published as aerosol depolarization potentials and are converted to particle linear depolarization ratios (see Burton et al., 2014; Cairo et al., 1999; Gimmestad, 2008).

The measured depolarization ratios for the presented dust cases (Cases 1, 2,3) are mostly higher than these literature values for dust measured in or close to Central Asia. This suggests that those studies might also have described observations of polluted or mixed dust. The range of the presented particle depolarization ratios $(0.31-0.35)$ at $532 \mathrm{~nm}$ wavelength is comparable with the values of fresh Saharan dust (0.27-0.35; Freudenthaler et al., 2009) or Middle Eastern dust (0.25-0.32; Mamouri et al., 2016). The spectral difference between the wavelengths is considerable. The range of the presented particle depolarization ratios at $355 \mathrm{~nm}$ wavelength $(0.18-0.29)$ is large, with the exceptionally high value during the most extreme dust event (Case 3). In Saharan dust, particle depolarization ratios at $355 \mathrm{~nm}$ wavelength in 
the range of $0.22-0.31$ were measured at the source region (Freudenthaler et al., 2009) and 0.21-0.27 after long-range transport (Burton et al., 2015; Groß et al., 2015; Haarig et al., 2016, 2017). The near-ground dust cases (Cases 2, 3) had higher particle depolarization ratios at both wavelengths than the lofted dust layer of Case 1. Nevertheless, the lofted dust layer in Case 1 had a depolarization ratio of 0.31 at $532 \mathrm{~nm}$ wavelength, which indicates only minor changes in Middle Eastern dust depolarization characteristics during its long-range transport towards Central Asia. However, the lofted dust layer in Case 1 had a lower depolarization ratio at $355 \mathrm{~nm}$ wavelength than long-range transported Saharan dust.

\section{Conclusions}

For the first time, multiwavelength polarization Raman lidar observations have been carried out in Tajikistan in the framework of the CADEX campaign. The continuous 18-month measurements provide a unique data set of vertically resolved aerosol optical properties in Central Asia. Additional ground-based in situ measurements and modeling studies accompanied the CADEX campaign (not presented here). During the campaign, dust layers were observed frequently from the surface to tropopause heights, having source regions in Africa, the Middle East, and Central Asia. Four case studies, which are typical for the conditions at the location, have been presented including lofted dust layers and extreme dust events. As a contrast to the dust cases, an example of a pollution aerosol layer of local origin illustrates the non-negligible anthropogenic influence on the aerosol in Tajikistan. The observed particle linear depolarization ratios for the dust cases range from 0.18 to 0.29 at $355 \mathrm{~nm}$ and 0.31 to 0.35 at $532 \mathrm{~nm}$ wavelength. The presented examples of near-ground layers of Central Asian dust had high depolarization ratios at both wavelengths indicating pure dust conditions. The presented lofted dust layer of long-range transported Middle Eastern dust had slightly lower depolarization ratios, especially at $355 \mathrm{~nm}$ wavelength. Nevertheless, the values still indicate almost unpolluted dust conditions after long-range transport to Central Asia. The observed lidar ratios in the presented dust cases range from 40.3 to $46.9 \mathrm{sr}$ at $355 \mathrm{~nm}$ and from 35.7 to $42.9 \mathrm{sr}$ at $532 \mathrm{~nm}$ wavelength. These lidar ratio values are lower than typical lidar ratios of Saharan dust (50-60 sr) and comparable to lidar ratios of dust from the Middle East or west-Asia (35-45 sr). Further analyses of the data set, to be published in a follow-up publication, include a statistical analysis of the whole measurement period regarding the optical properties, dust mass concentrations, dust layer heights, seasons, and source regions.

Nevertheless, more measurements in Central Asia are needed to analyze long-term trends, especially with respect to climate change. Such measurements also offer new satellite comparison possibilities. Moreover, the assimilation of these data into dust models (regional and global transport, aerosol optical properties, and radiative transfer) will help to reduce uncertainties. Therefore, a permanent lidar station in Tajikistan will be established starting most likely from 2019.

Data availability. HYSPLIT backward trajectories are calculated via the available online tools (Stein et al., 2015; Rolph et al., 2017; http://ready.arl.noaa.gov/HYSPLIT.php). AERONET sun photometer data are available from the AERONET web page (http://aeronet.gsfc.nasa.gov/cgi-bin/type_one_station_ opera_v2_new?site=Dushanbe). GDAS data is available at https://www.ready.noaa.gov/gdas1.php (GDAS, 2017). Data of the FLEXPART backward trajectory calculations and the CADEX Polly XT lidar data are available at the Leibniz Institute for Tropospheric Research, Leipzig.

Competing interests. The authors declare that they have no conflict of interest.

Acknowledgements. The CADEX project was funded by the German Federal Ministry of Education and Research (BMBF) in the context of "Partnerships for sustainable problem solving in emerging and developing countries" under the grant number 01DK14014. This project has also received funding from the European Union's Horizon 2020 research and innovation programme under grant agreement no. 654109. We would like to thank the Academy of Sciences of Tajikistan for the helpful support of any kind during all stages of the CADEX campaign. We would like to thank Lars Klüser from the German Aerospace Center, Emmanouil Proestakis from the National Observatory of Athens, and Alexandra Chudnovsky from the University of Tel Aviv for the opportunity to compare the ground-based measurements to satellite measurements. Konrad Kandler acknowledges support from the Deutsche Forschungsgemeinschaft (grant KA2280/2).

The publication of this article was funded by the open-access fund of Leibniz Universität Hannover.

Edited by: Matthias Tesche

Reviewed by: three anonymous referees

\section{References}

Abdullaev, S. F., Nazarov, B. I., Salikhov, T., and Maslov, V. A.: Correlations of surface air temperature and optical thickness of arid aerosol according to AERONET data, Atmos. Ocean. Opt., 25, 428-433, 2012.

Althausen, D., Engelmann, R., Baars, H., Heese, B., Ansmann, A., Müller, D., and Komppula, M.: Portable Raman Lidar Polly XT for Automated Profiling of Aerosol Backscatter, Extinction, and Depolarization, J. Atmos. Ocean. Tech., 26, 2366-2378, https://doi.org/10.1175/2009JTECHA1304.1, 2009.

Amiridis, V., Wandinger, U., Marinou, E., Giannakaki, E., Tsekeri, A., Basart, S., Kazadzis, S., Gkikas, A., Taylor, M., Bal- 
dasano, J., and Ansmann, A.: Optimizing CALIPSO Saharan dust retrievals, Atmos. Chem. Phys., 13, 12089-12106, https://doi.org/10.5194/acp-13-12089-2013, 2013.

Andronova, A. V., Gomes, L., Smirnov, V. V., Ivanov, A. V., and Shukurova, L. M.: Physico-chemical characteristics of dust aerosols deposited during the Soviet-American experiment (Tadzhikistan, 1989), Atmos. Environ., 27, 2487-2493, https://doi.org/10.1016/0960-1686(93)90020-Y, 1993.

Ansmann, A., Petzold, A., Kandler, K., Tegen, I., Wendisch, M., Müller, D., Weinzierl, B., Müller, T., and Heintzenberg, J.: Saharan Mineral Dust Experiments SAMUM-1 and SAMUM-2: what have we learned?, Tellus B, 63, 403-429, https://doi.org/10.1111/j.1600-0889.2011.00555.x, 2011a.

Ansmann, A., Tesche, M., Seifert, P., Groß, S., Freudenthaler, V., Apituley, A., Wilson, K. M., Serikov, I., Linné, H., Heinold, B., Hiebsch, A., Schnell, F., Schmidt, J., Mattis, I., Wandinger, U., and Wiegner, M.: Ash and fine-mode particle mass profiles from EARLINET-AERONET observations over central Europe after the eruptions of the Eyjafjallajökull volcano in 2010, J. Geophys. Res.-Atmos., 116, D00U02, https://doi.org/10.1029/2010JD015567, 2011b.

Ansmann, A., Seifert, P., Tesche, M., and Wandinger, U.: Profiling of fine and coarse particle mass: case studies of Saharan dust and Eyjafjallajökull/Grimsvötn volcanic plumes, Atmos. Chem. Phys., 12, 9399-9415, https://doi.org/10.5194/acp12-9399-2012, 2012.

Baars, H.: Aerosol profiling with lidar in the Amazon Basin during the wet and dry season 2008, PhD thesis, University of Leipzig, Leipzig, 2011.

Baars, H., Ansmann, A., Althausen, D., Engelmann, R., Heese, B., Müller, D., Artaxo, P., Paixao, M., Pauliquevis, T., and Souza, R.: Aerosol profiling with lidar in the Amazon Basin during the wet and dry season, J. Geophys. Res.-Atmos., 117, D21201, https://doi.org/10.1029/2012JD018338, 2012.

Baars, H., Kanitz, T., Engelmann, R., Althausen, D., Heese, B., Komppula, M., Preißler, J., Tesche, M., Ansmann, A., Wandinger, U., Lim, J.-H., Ahn, J. Y., Stachlewska, I. S., Amiridis, V., Marinou, E., Seifert, P., Hofer, J., Skupin, A., Schneider, F., Bohlmann, S., Foth, A., Bley, S., Pfüller, A., Giannakaki, E., Lihavainen, H., Viisanen, Y., Hooda, R. K., Pereira, S. N., Bortoli, D., Wagner, F., Mattis, I., Janicka, L., Markowicz, K. M., Achtert, P., Artaxo, P., Pauliquevis, T., Souza, R. A. F., Sharma, V. P., van Zyl, P. G., Beukes, J. P., Sun, J., Rohwer, E. G., Deng, R., Mamouri, R.-E., and Zamorano, F.: An overview of the first decade of Polly NET: an emerging network of automated Raman-polarization lidars for continuous aerosol profiling, Atmos. Chem. Phys., 16, 5111-5137, https://doi.org/10.5194/acp16-5111-2016, 2016.

Balance, R. and Pant, B. D. (Eds.): Environment Statistic in Central Asia: Progress and Prospects, ERD Working Paper Series No. 36, Asian Development Bank Manila, Philippines, 2003.

Bayat, A., Masoumi, A., and Khalesifard, H. R.: Retrieval of atmospheric optical parameters from ground-based sun-photometer measurements for Zanjan, Iran, Atmos. Meas. Tech., 4, 857-863, https://doi.org/10.5194/amt-4-857-2011, 2011.

Bi, J., Huang, J., Holben, B., and Zhang, G.: Comparison of key absorption and optical properties between pure and transported anthropogenic dust over East and Central Asia, Atmos. Chem.
Phys., 16, 15501-15516, https://doi.org/10.5194/acp-16-155012016, 2016.

Bravo-Aranda, J. A., Titos, G., Granados-Muñoz, M. J., GuerreroRascado, J. L., Navas-Guzmán, F., Valenzuela, A., Lyamani, H., Olmo, F. J., Andrey, J., and Alados-Arboledas, L.: Study of mineral dust entrainment in the planetary boundary layer by lidar depolarisation technique, Tellus B, 67, 26180, https://doi.org/10.3402/tellusb.v67.26180, 2015.

Burton, S. P., Vaughan, M. A., Ferrare, R. A., and Hostetler, C. A.: Separating mixtures of aerosol types in airborne High Spectral Resolution Lidar data, Atmos. Meas. Tech., 7, 419-436, https://doi.org/10.5194/amt-7-419-2014, 2014.

Burton, S. P., Hair, J. W., Kahnert, M., Ferrare, R. A., Hostetler, C. A., Cook, A. L., Harper, D. B., Berkoff, T. A., Seaman, S. T., Collins, J. E., Fenn, M. A., and Rogers, R. R.: Observations of the spectral dependence of linear particle depolarization ratio of aerosols using NASA Langley airborne High Spectral Resolution Lidar, Atmos. Chem. Phys., 15, 13453-13473, https://doi.org/10.5194/acp-15-13453-2015, 2015.

Cairo, F., Di Donfrancesco, G., Adriani, A., Pulvirenti, L., and Fierli, F.: Comparison of various linear depolarization parameters measured by lidar, Appl. Optics, 38, 4425-4432, https://doi.org/10.1364/AO.38.004425, 1999.

Caquineau, S., Gaudichet, A., Gomes, L., and Legrand, M.: Mineralogy of Saharan dust transported over Northwestern tropical Atlantic Ocean in relation to source regions, J. Geophys. Res.-Atmos., 107, 4251, https://doi.org/10.1029/2000JD000247, 2002.

Chatenoux, B.: Central Asia Glaciers' Study - Current state of knowledge and recommendations, Central Asian Climate Risk Management Programme (CA-CRM), Literature and data review, gaps' identification and recommendations for future work prepared by UNEP/DEWA/GRID-Europe, 2011.

Chen, B. and Sverdlik, L.: Optical and microphysical characteristics of aerosol structures in Central Asia, in: International Conf. on Lasers, Applications, and Technologies 2007: Environmental Monitoring and Ecological Applications, Optical Sensors in Bio, Chemical, and Engineering Technologies, and Femtosecond Laser Pulse Filamentation, vol. 6733, https://doi.org/10.1117/12.753117, 2007.

Chen, B. B., Sverdlik, L. G., Imashev, S. A., Solomon, P. A., Lantz, J., Schauer, J. J., Shafer, M. M., Artamonova, M. S., and Carmichael, G. R.: Lidar Measurements of the Vertical Distribution of Aerosol Optical and Physical Properties over Central Asia, Int. J. Atmos. Sci., 261546, https://doi.org/10.1155/2013/261546, 2013.

Chen, Y., Li, W., Fang, G., and Li, Z.: Review article: Hydrological modeling in glacierized catchments of central Asia status and challenges, Hydrol. Earth Syst. Sci., 21, 669-684, https://doi.org/10.5194/hess-21-669-2017, 2017.

Chin, M., Diehl, T., Ginoux, P., and Malm, W.: Intercontinental transport of pollution and dust aerosols: implications for regional air quality, Atmos. Chem. Phys., 7, 5501-5517, https://doi.org/10.5194/acp-7-5501-2007, 2007.

Darmenova, K., Sokolik, I. N., Shao, Y., Marticorena, B., and Bergametti, G.: Development of a physically based dust emission module within the Weather Research and Forecasting (WRF) model: Assessment of dust emission parameterizations and input parameters for source regions in Cen- 
tral and East Asia, J. Geophys. Res.-Atmos., 114, D14201, https://doi.org/10.1029/2008JD011236, 2009.

Dieudonné, E., Chazette, P., Marnas, F., Totems, J., and Shang, X.: Lidar profiling of aerosol optical properties from Paris to Lake Baikal (Siberia), Atmos. Chem. Phys., 15, 5007-5026, https://doi.org/10.5194/acp-15-5007-2015, 2015.

Engelmann, R., Kanitz, T., Baars, H., Heese, B., Althausen, D., Skupin, A., Wandinger, U., Komppula, M., Stachlewska, I. S., Amiridis, V., Marinou, E., Mattis, I., Linné, H., and Ansmann, A.: The automated multiwavelength Raman polarization and water-vapor lidar Polly XT: the neXT generation, Atmos. Meas. Tech., 9, 1767-1784, https://doi.org/10.5194/amt-9-1767-2016, 2016.

Fomba, K. W., Müller, K., van Pinxteren, D., Poulain, L., van Pinxteren, M., and Herrmann, H.: Long-term chemical characterization of tropical and marine aerosols at the Cape Verde Atmospheric Observatory (CVAO) from 2007 to 2011, Atmos. Chem. Phys., 14, 8883-8904, https://doi.org/10.5194/acp-148883-2014, 2014.

Fraser, R. S.: Optical thickness of atmospheric dust over Tadzhikistan, Atmos. Environ., 27, 2533-2538, https://doi.org/10.1016/0960-1686(93)90026-U, 1993.

Freedman, E. and Neuzil, M., eds.: Environmental Crises in Central Asia: From steppes to seas, from deserts to glaciers, Routledge Studies in Environmental Communication and Media, Taylor \& Francis, Oxford, 2015.

Freudenthaler, V.: About the effects of polarising optics on lidar signals and the $\Delta 90$ calibration, Atmos. Meas. Tech., 9, 41814255, https://doi.org/10.5194/amt-9-4181-2016, 2016.

Freudenthaler, V., Esselborn, M., Wiegner, M., Heese, B., Tesche, M., Ansmann, A., Müller, D., Althausen, D., Wirth, M., Fix, A., Ehret, G., Knippertz, P., Toledano, C., Gasteiger, J., Garhammer, M., and Seefeldner, M.: Depolarization ratio profiling at several wavelengths in pure Saharan dust during SAMUM 2006, Tellus B, 61, 165-179, https://doi.org/10.1111/j.16000889.2008.00396.x, 2009.

Gabbi, J., Huss, M., Bauder, A., Cao, F., and Schwikowski, M.: The impact of Saharan dust and black carbon on albedo and long-term mass balance of an Alpine glacier, The Cryosphere, 9, 13851400, https://doi.org/10.5194/tc-9-1385-2015, 2015.

GDAS: Global Data Assimilation System, meteorological data base, available at: https://www.ready.noaa.gov/gdas1.php, last access: 20 February 2017

Georgoulias, A. K., Alexandri, G., Kourtidis, K. A., Lelieveld, J., Zanis, P., Pöschl, U., Levy, R., Amiridis, V., Marinou, E., and Tsikerdekis, A.: Spatiotemporal variability and contribution of different aerosol types to the aerosol optical depth over the Eastern Mediterranean, Atmos. Chem. Phys., 16, 13853-13884, https://doi.org/10.5194/acp-16-13853-2016, 2016.

Giannakaki, E., van Zyl, P. G., Müller, D., Balis, D., and Komppula, M.: Optical and microphysical characterization of aerosol layers over South Africa by means of multi-wavelength depolarization and Raman lidar measurements, Atmos. Chem. Phys., 16, 81098123, https://doi.org/10.5194/acp-16-8109-2016, 2016.

Gillette, D. A. and Dobrowolski, J. P.: Soil crust formation by dust deposition at Shaartuz, Tadzhik, S.S.R., Atmos. Environ., 27, 2519-2525, https://doi.org/10.1016/0960-1686(93)90024-S, 1993.
Gillette, D. A., Bodhaine, B. A., and Mackinnon, D.: Transport and deposition of desert dust in the Kafirnigan River Valley (Tadzhikistan) from Shaartuz to Esanbay: Measurements and a simple model, Atmos. Environ., 27, 2545-2552, https://doi.org/10.1016/0960-1686(93)90028-W, 1993.

Gimmestad, G. G.: Reexamination of depolarization in lidar measurements, Appl. Optics, 47, 3795-3802, https://doi.org/10.1364/AO.47.003795, 2008.

Gkikas, A., Hatzianastassiou, N., and Mihalopoulos, N.: Aerosol events in the broader Mediterranean basin based on 7-year (2000-2007) MODIS C005 data, Ann. Geophys., 27, 35093522, https://doi.org/10.5194/angeo-27-3509-2009, 2009.

Gkikas, A., Hatzianastassiou, N., Mihalopoulos, N., Katsoulis, V., Kazadzis, S., Pey, J., Querol, X., and Torres, O.: The regime of intense desert dust episodes in the Mediterranean based on contemporary satellite observations and ground measurements, Atmos. Chem. Phys., 13, 12135-12154, https://doi.org/10.5194/acp-13-12135-2013, 2013.

Gkikas, A., Basart, S., Hatzianastassiou, N., Marinou, E., Amiridis, V., Kazadzis, S., Pey, J., Querol, X., Jorba, O., Gassó, S., and Baldasano, J. M.: Mediterranean intense desert dust outbreaks and their vertical structure based on remote sensing data, Atmos. Chem. Phys., 16, 8609-8642, https://doi.org/10.5194/acp16-8609-2016, 2016.

Golitsyn, G. and Gillette, D. A.: Introduction: A joint SovietAmerican experiment for the study of Asian desert dust and its impact on local meteorological conditions and climate, Atmos. Environ., 27, 2467-2470, https://doi.org/10.1016/09601686(93)90017-S, 1993.

Golitsyn, G. S., Gillette, D. A., and Johnson, T. (Eds.): Joint SovietAmerican Experiment on Arid Aerosol, Hydrometeoizdat, St. Petersburg, 1993a.

Golitsyn, G. S., Shukurov, A. K., Abdullaev, S. F., and Nazarov, B. I.: On the surface air cooling due too dust atmospheric turbidity, 67-78, in: Golitsyn et al. (1993a), 1993 b.

Gomes, L. and Gillette, D. A.: A comparison of characteristics of aerosol from dust storms in Central Asia with soilderived dust from other regions, Atmos. Environ., 27, 25392544, https://doi.org/10.1016/0960-1686(93)90027-V, 1993.

Griffin, D. W.: Atmospheric Movement of Microorganisms in Clouds of Desert Dust and Implications for Human Health, Clin. Microbiol. Rev., 20, 459-477, https://doi.org/10.1128/CMR.00039-06, 2007.

Groll, M., Opp, C., and Aslanov, I.: Spatial and temporal distribution of the dust deposition in Central Asia - results from a long term monitoring program, Aeolian Res., 9, 49-62, https://doi.org/10.1016/j.aeolia.2012.08.002, 2013.

Groß, S., Tesche, M., Freudenthaler, V., Toledano, C., Wiegner, M., Ansmann, A., Althausen, D., and Seefeldner, M.: Characterization of Saharan dust, marine aerosols and mixtures of biomassburning aerosols and dust by means of multi-wavelength depolarization and Raman lidar measurements during SAMUM 2, Tellus B, 64, 706-724, https://doi.org/10.1111/j.16000889.2011.00556.x, 2011.

Groß, S., Freudenthaler, V., Schepanski, K., Toledano, C., Schäfler, A., Ansmann, A., and Weinzierl, B.: Optical properties of long-range transported Saharan dust over Barbados as measured by dual-wavelength depolarization Raman li- 
dar measurements, Atmos. Chem. Phys., 15, 11067-11080, https://doi.org/10.5194/acp-15-11067-2015, 2015.

Haarig, M., Althausen, D., Ansmann, A., Klepel, A., Baars, H., Engelmann, R., Groß, S., and Freudenthaler, V.: Measurement of the Linear Depolarization Ratio of Aged Dust at Three Wavelengths (355, 532 and $1064 \mathrm{~nm})$ Simultaneously over Barbados, in: EPJ Web of Conferences Volume 119 (2016): The 27th International Laser Radar Conference (ILRC 27), edited by: Gross, B., Moshary, F., and Arend, M., vol. 119, p. 18009, https://doi.org/10.1051/epjconf/201611918009, 2016.

Haarig, M., Ansmann, A., Althausen, D., Klepel, A., Groß, S., Freudenthaler, V., Toledano, C., Mamouri, R.-E., Farrell, D. A., Prescod, D. A., Marinou, E., Burton, S. P., Gasteiger, J., Engelmann, R., and Baars, H.: Triple-wavelength depolarizationratio profiling of Saharan dust over Barbados during SALTRACE in 2013 and 2014, Atmos. Chem. Phys., 17, 10767-10794, https://doi.org/10.5194/acp-17-10767-2017, 2017.

Hansen, A. D. A., Kapustin, V. A., Kopeikin, V. M., Gillette, D. A., and Bodhaine, B. A.: Optical absorption by aerosol black carbon and dust in a desert region of Central Asia, Atmos. Environ., 27, 2527-2531, https://doi.org/10.1016/0960-1686(93)90025-T, 1993.

Hara, K. and Zhang, D.: Bacterial abundance and viability in long-range transported dust, Atmos. Environ., 47, 20-25, https://doi.org/10.1016/j.atmosenv.2011.11.050, 2012.

Heinold, B., Tegen, I., Bauer, S., and Wendisch, M.: Regional modelling of Saharan dust and biomass-burning smoke Part 2: Direct radiative forcing and atmospheric dynamic response, Tellus B, 63, 800-813, https://doi.org/10.1111/j.1600-0889.2011.00574.x, 2011.

Heinold, B., Tegen, I., Schepanski, K., and Banks, J. R.: New developments in the representation of Saharan dust sources in the aerosol-climate model ECHAM6-HAM2, Geosci. Model Dev., 9, 765-777, https://doi.org/10.5194/gmd-9-765-2016, 2016.

Heintzenberg, J.: The SAMUM-1 experiment over Southern Morocco: overview and introduction, Tellus B, 61, 2-11, https://doi.org/10.1111/j.1600-0889.2008.00403.x, 2009.

Holben, B. N., Eck, T. F., Slutsker, I., Tanré, D., Buis, J. P., Setzer, A., E., V., Reagan, J. A., Kaufman, Y. J., Nakajima, T., Lavenu, F., Jankowiak, I., and Smirnov, A.: AERONET - A Federated Instrument Network and Data Archive for Aerosol Characterization, Remote Sens. Environ., 66, 1-16, https://doi.org/10.1016/S0034-4257(98)00031-5, 1998.

Iwasaka, Y., Shi, G.-Y., Yamada, M., Matsuki, A., Trochkine, D., Kim, Y. S., Zhang, D., Nagatani, T., Shibata, T., Nagatani, M., Nakata, H., Shen, Z., Li, G., and Chen, B.: Importance of dust particles in the free troposphere over the Taklamakan Desert: Electron microscopic experiments of particles collected with a balloonborne particle impactor at Dunhuang, China, J. Geophys. Res.-Atmos, 108, 8644, https://doi.org/10.1029/2002JD003270, 2003.

Jin, Y., Kai, K., Shibata, T., Zhang, K., and Zhou, H.: Validation of the Dust Layer Structure over the Taklimakan Desert, China by the CALIOP Space-Borne Lidar Using Ground-Based Lidar, SOLA, 6, 121-124, https://doi.org/10.2151/sola.2010-031, 2010.

Kai, K., Nagata, Y., Tsunematsu, N., Matsumura, T., Kim, H.S., Matsumoto, T., Hu, S., Zhou H., Abo, M., and Nagai, T.: The structure of the dust layer over the Taklimakan Desert during the dust storm in April 2002 as observed us- ing a depolarization lidar, J. Meteorol. Soc. Jpn., 86, 1-16, https://doi.org/10.2151/jmsj.86.1, 2008.

Kandler, K., Schütz, L., Deutscher, C., Ebert, M., Hofmann, H., Jäckel, S., Jaenicke, R., Knippertz, P., Lieke, K., Massling, A., Petzold, A., Schladitz, A., Weinzierl, B., Wiedensohler, A., Zorn, S., and Weinbruch, S.: Size distribution, mass concentration, chemical and mineralogical composition and derived optical parameters of the boundary layer aerosol at Tinfou, Morocco, during SAMUM 2006, Tellus B, 61, 32-50, https://doi.org/10.1111/j.1600-0889.2008.00385.x, 2009.

Kandler, K., Lieke, K., Benker, N., Emmel, C., Küpper, M., MüllerEbert, D., Ebert, M., Scheuvens, D., Schladitz, A., Schütz, L., and Weinbruch, S.: Electron microscopy of particles collected at Praia, Cape Verde, during the Saharan Mineral Dust Experiment: particle chemistry, shape, mixing state and complex refractive index, Tellus B, 63, 475-496, https://doi.org/10.1111/j.16000889.2011.00550.x, 2011.

Kanitz, T., Ansmann, A., Engelmann, R., and Althausen, D.: Northsouth cross sections of the vertical aerosol distribution over the Atlantic Ocean from multiwavelength Raman/polarization lidar during Polarstern cruises, J. Geophys. Res.-Atmos., 118, 26432655, https://doi.org/10.1002/jgrd.50273, 2013.

Kayumov, A.: Glaciers Resources of Tajikistan in Condition of the Climate Change, State Agency for Hydrometeorology of Committee for Environmental Protection under the Government of the Republic of Tajikistan, 2010.

Kayumov, A. K. and Novikov, V. V.: The Third National Communication of the Republic of Tajikistan under the United Nations Framework Convention on Climate Change, Tech. rep., The State Agency for Hydrometeorology, Committee for environmental protection under the of the Republic of Tajikistan, Dushanbe, available at: http://unfccc.int/resource/docs/natc/tjknc3_eng.pdf (last access: 10 June 2017), 2014.

Klüser, L., Martynenko, D., Banks, J. R., Bergemann, C., Brindley, H. E., and Holzer-Popp, T.: Information content of spaceborne hyperspectral infrared observations with respect to mineral dust properties, Remote Sens. Environ., 156, 294-309, https://doi.org/10.1016/j.rse.2014.09.036, 2015.

Lioubimtseva, E. and Henebry, G. M.: Climate and environmental change in arid Central Asia: Impacts, vulnerability, and adaptations, J. Arid Environ., 73, 963-977, https://doi.org/10.1016/j.jaridenv.2009.04.022, 2009.

Liu, Z., Sugimoto, N., and Murayama, T.: Extinction-tobackscatter ratio of Asian dust observed with high-spectralresolution lidar and Raman lidar, Appl. Optics, 41, 2760-2767, https://doi.org/10.1364/AO.41.002760, 2002.

Makhmadaliev, B. and Novikov, V. V.: The First National Communication of the Republic of Tajikistan under the United Nations Framework Convention on Climate Change, Tech. rep., Ministry for Nature Protection of the Republic of Tajikistan, The Main Administration on Hydrometeorology and Environmental Monitoring, Dushanbe, available at: http://unfccc.int/resource/docs/ natc/tainc1.pdf (last access: 10 June 2017), 2002.

Makhmadaliev, B. U., Novikov, V. V., and Kayumov, A. K.: The First National Communication of the Republic of Tajikistan under the United Nations Framework Convention on Climate Change, Phase 2, Tech. rep., Ministry for Nature Protection of the Republic of Tajikistan, The Main Administration on Hydrometeorology and Environmental Monitoring, Dushanbe, avail- 
able at: http://unfecc.int/resource/docs/natc/tajncladd.pdf (last access: 10 June 2017), 2004.

Makhmadaliev, B. U., Kayumov, A. K., Novikov, V. V., Mustaeva, N., and Rajobov, I.: The Second National Communication of the Republic of Tajikistan under the United Nations Framework Convention on Climate Change, Tech. rep., The State Agency for Hydrometeorology, Committee for environmental protection under the of the Republic of Tajikistan, Dushanbe, available at: http://unfccc.int/resource/docs/natc/tainc2.pdf (last access: 10 June 2017), 2008.

Mamouri, R. E. and Ansmann, A.: Fine and coarse dust separation with polarization lidar, Atmos. Meas. Tech., 7, 3717-3735, https://doi.org/10.5194/amt-7-3717-2014, 2014.

Mamouri, R.-E. and Ansmann, A.: Potential of polarization/Raman lidar to separate fine dust, coarse dust, maritime, and anthropogenic aerosol profiles, Atmos. Meas. Tech., 10, 3403-3427, https://doi.org/10.5194/amt-10-3403-2017, 2017.

Mamouri, R. E., Ansmann, A., Nisantzi, A., Kokkalis, P., Schwarz, A., and Hadjimitsis, D. G.: Low Arabian dust extinctionto-backscatter ratio, Geophys. Res. Lett., 40, 4762-4766, https://doi.org/10.1002/grl.50898, 2013.

Mamouri, R.-E., Ansmann, A., Nisantzi, A., Solomos, S., Kallos, G., and Hadjimitsis, D. G.: Extreme dust storm over the eastern Mediterranean in September 2015: satellite, lidar, and surface observations in the Cyprus region, Atmos. Chem. Phys., 16, 13711-13724, https://doi.org/10.5194/acp-16-13711-2016, 2016

Mikami, M., Shi, G. Y., Uno, I., Yabuki, S., Iwasaka, Y., Yasui, M., Aoki, T., Tanaka, T. Y., Kurosaki, Y., Masuda, K., Uchiyama, A., Matsuki, A., Sakai, T., Takemi, T., Nakawo, M., Seino, N., Ishizuka, M., Satake, S., Fujita, K., Hara, Y., Kai, K., Kanayama, S., Hayashi, M., Du, M., Kanai, Y., Yamada, Y., Zhang, X. Y., Shen, Z., Zhou, H., Abe, O., Nagai, T., Tsutsumi, Y., Chiba, M., and Suzuk, J.: Aeolian dust experiment on climate impact: An overview of Japan China joint project ADEC, Global Planet. Change, 52, 142-172, https://doi.org/10.1016/j.gloplacha.2006.03.001, 2006.

Miller-Schulze, J. P., Shafer, M. M., Schauer, J. J., Solomon, P. A., Lantz, J., Artamonova, M., Chen, B., Imashev, S., Sverdlik, L., Carmichael, G. R., and Deminter, J. T.: Characteristics of fine particle carbonaceous aerosol at two remote sites in Central Asia, Atmos. Environ., 45, 695-6964, https://doi.org/10.1016/j.atmosenv.2011.09.026, 2011.

Müller, D., Ansmann, A., Mattis, I., Tesche, M., Wandinger, U., Althausen, D., and Pisani, G.: Aerosol-type-dependent lidar ratios observed with Raman lidar, J. Geophys. Res.-Atmos., 112, D16202, https://doi.org/10.1029/2006JD008292, 2007.

Nazarov, B. I., Abdullaev, S. F., and Maslov, V. A.: Studies of Temperature Effects of Dust Storms, Izv. Atmos. Ocean. Phys., 46, 475-481, 2010a.

Nazarov, B. I., Maslov, V. A., and Abdullaev, S. F.: Optical and Microphysical Parameters of Arid Dust Aerosol, Izv. Atmos. Ocean. Phys., 46, 468-474, 2010b.

Nisantzi, A., Mamouri, R. E., Ansmann, A., Schuster, G. L., and Hadjimitsis, D. G.: Middle East versus Saharan dust extinctionto-backscatter ratios, Atmos. Chem. Phys., 15, 7071-7084, https://doi.org/10.5194/acp-15-7071-2015, 2015.

Nobakht, M., Shahgedanova, M., and White, K.: Characterization of dust sources in Central Asia using Remote Sensing, AGU Fall Meeting Abstracts, 2015.
Ott, D. K. and Peters, T.: A Shelter to Protect a Passive Sampler for Coarse Particulate Matter, PM10-2.5, Aerosol Sci. Tech., 42, 299-309, https://doi.org/10.1080/02786820802054236, 2008.

Pachenko, M. V., Terpugova, S. A., Bodhaine, B. A., Isakov, A. A., Sviridenkov, M. A., Sokolik, I. N., Romashova, E. V., Nazarov, B. I., Shukurov, A. K., Chistyakova, E. I., and Johnson, T. C.: Optical investigations of dust storms during U.S.S.R.-U.S. experiments in Tadzhikistan, 1989, Atmos. Environ., 27, 2503-2508, https://doi.org/10.1016/0960-1686(93)90023-R, 1993.

Park, J., Ichijo, T., Nasu, M., and Yamaguchi, N.: Investigation of bacterial effects of Asian dust events through comparison with seasonal variability in outdoor airborne bacterial community, Sci. Rep., 6, 35706, https://doi.org/10.1038/srep35706, 2016.

Ridley, D. A., Heald, C. L., Kok, J. F., and Zhao, C.: An observationally constrained estimate of global dust aerosol optical depth, Atmos. Chem. Phys., 16, 15097-15117, https://doi.org/10.5194/acp-16-15097-2016, 2016.

Rolph, G., Stein, A., and Stunder, B.: Real-time Environmental Applications and Display sYstem: READY Environ. Modell. Soft., 95, 210-228, https://doi.org/10.1016/j.envsoft.2017.06.025, 2017.

Ryder, C. L., McQuaid, J. B., Flamant, C., Rosenberg, P. D., Washington, R., Brindley, H. E., Highwood, E. J., Marsham, J. H., Parker, D. J., Todd, M. C., Banks, J. R., Brooke, J. K., Engelstaedter, S., Estelles, V., Formenti, P., Garcia-Carreras, L., Kocha, C., Marenco, F., Sodemann, H., Allen, C. J. T., Bourdon, A., Bart, M., Cavazos-Guerra, C., Chevaillier, S., Crosier, J., Darbyshire, E., Dean, A. R., Dorsey, J. R., Kent, J., O’Sullivan, D., Schepanski, K., Szpek, K., Trembath, J., and Woolley, A.: Advances in understanding mineral dust and boundary layer processes over the Sahara from Fennec aircraft observations, Atmos. Chem. Phys., 15, 8479-8520, https://doi.org/10.5194/acp15-8479-2015, 2015.

Sakai, T., Nagai, T., Nakazato, M., Mano, Y., and Matsumura, T.: Ice clouds and Asian dust studied with lidar measurements of particle extinction-to-backscatter ratio, particle depolarization, and water-vapor mixing ratio over Tsukuba, Appl. Optics, 42, 7103-7116, https://doi.org/10.1364/AO.42.007103, 2003.

Schettler, G., Shabunin, A., Kemnitz, H., Knoeller, K., Imashev, S., Rybin, A., and Wetzel, H.-U.: Seasonal and diurnal variations in dust characteristics on the northern slopes of the Tien Shan - Grain-size, mineralogy, chemical signatures and isotope composition of attached nitrate, J. Asian Earth Sci., 88, 257-276, https://doi.org/10.1016/j.jseaes.2014.03.019, 2014.

Schmale, J., Flanner, M., Kang, S., Sprenger, M., Zhang, Q., Guo, J., Yang Li, Y., Schwikowski, M., and Farinotti, D.: Modulation of snow reflectance and snowmelt from Central Asian glaciers by anthropogenic black carbon, Sci. Rep., 7, 40501, https://doi.org/10.1038/srep40501, 2017.

Schuster, G. L., Vaughan, M., MacDonnell, D., Su, W., Winker, D., Dubovik, O., Lapyonok, T., and Trepte, C.: Comparison of CALIPSO aerosol optical depth retrievals to AERONET measurements, and a climatology for the lidar ratio of dust, Atmos. Chem. Phys., 12, 7431-7452, https://doi.org/10.5194/acp12-7431-2012, 2012.

Schwarz, A.: Aerosol typing over Europe and its benefits for the CALIPSO and EarthCARE missions - Statistical analysis based on multiwavelength aerosol lidar measurements from ground-based EARLINET stations and comparison to 
spaceborne CALIPSO data, PhD thesis, University of Leipzig, Leipzig, 2015.

Semenov, V. K., Smirnov, A., Aref'ev, V. N., Sinyakov, V. P., Sorokina, L. I., and Ignatova, N. I.: Aerosol optical depth over the mountainous region in central Asia (IssykKul Lake, Kyrgyzstan), Geophys. Res. Lett., 32, L05807, https://doi.org/10.1029/2004GL021746, 2005.

Shukurov, A. K., Nazarov, B. I., Abdullaev, S. F., and Pirogov, S. V.: On optical depth ratios of dust aerosol in visible and infrared spectra regions, 83-88, in: Golitsyn et al. (1993a), 1993.

Siegfried, T., Bernauer, T., Guiennet, R., Sellars, S., Robertson, A. W., Mankin, J., Bauer-Gottwein, P., and Yakovlev, A.: Will climate change exacerbate water stress in Central Asia?, Climatic Change, 112, 881-899, https://doi.org/10.1007/s10584011-0253-z, 2012.

Smirnov, V. V., Johnson, T. C., Krapivtseva, G. M., Krivchikova, T. V., and Shukurov, A. H.: Synoptic meteorological conditions during the U.S.S.R./U.S. dust experiment in Tadzhikistan in September 1989, Atmos. Environ., 27, 2471-2479, https://doi.org/10.1016/0960-1686(93)90018-T, 1993.

Smirnov, V. V., Gillette, D. A., Golitsyn, G. S., and MacKinnon, D. J.: The origin and evolution of dust clouds in Central Asia, Atmos. Res., 34, 169-176, https://doi.org/10.1016/01698095(94)90088-4, 1994.

Sokolik, I. N. and Golitsyn, G.: Investigation of optical and radiative properties of atmospheric dust aerosols, Atmos. Environ., 27, 2509-2517, https://doi.org/10.1016/0960-1686(93)90021-P, 1993.

Sokolik, I. N., Andronova, A. V., and Johnson, T. C.: Complex refractive index of atmospheric dust aerosols, Atmos. Environ., 27, 2495-2502, https://doi.org/10.1016/0960-1686(93)90021-P, 1993.

Sorg, A., Mosello, B., Shalpykova, G., Allan, A., Hill Clarvis, M., and Stoffel, M.: Coping with changing water resources: The case of the Syr Darya river basin in Central Asia, Environ. Sci. Policy, 43, 68-77, https://doi.org/10.1016/j.envsci.2013.11.003, 2014.

Stein, A. F., Draxler, R. R., Rolph, G. D., Stunder, B. J. B., Cohen, M. D., and Ngan, F.: NOAA's HYSPLIT atmospheric transport and dispersion modeling system, B. Am. Meteorol. Soc., 96, 2059-2077, https://doi.org/10.1175/BAMS-D-14$00110.1,2015$.

Stohl, A., Forster, C., Frank, A., Seibert, P., and Wotawa, G.: Technical note: The Lagrangian particle dispersion model FLEXPART version 6.2, Atmos. Chem. Phys., 5, 2461-2474, https://doi.org/10.5194/acp-5-2461-2005, 2005.

Su, L. and Toon, O. B.: Saharan and Asian dust: similarities and differences determined by CALIPSO, AERONET, and a coupled climate-aerosol microphysical model, Atmos. Chem. Phys., 11, 3263-3280, https://doi.org/10.5194/acp-11-3263-2011, 2011.

Tanaka, T. Y., Kurosaki, Y., Chiba, M., Matsumura, T., Nagai, T.and Yamazaki, A., Uchiyama, A., Tsunematsu, N., and Kai, K.: Possible transcontinental dust transport from North Africa and the Middle East to East Asia, Atmos. Environ., 39, 39013909, https://doi.org/10.1016/j.atmosenv.2005.03.034, 2005.

Tesche, M., Ansmann, A., Müller, D., Althausen, D., Engelmann, R., Hu, M., and Zhang, Y.: Particle backscatter, extinction, and lidar ratio profiling with Raman lidar in south and north China, Appl. Optics, 46, 6302-6308, https://doi.org/10.1364/AO.46.006302, 2007.
Tesche, M., Ansmann, A., Müller, D., Althausen, D., Engelmann, R., Freudenthaler, V., and Groß, S.: Vertically resolved separation of dust and smoke over Cape Verde by using multiwavelength Raman and polarization lidars during Saharan Mineral Dust Experiment 2008, J. Geophys. Res.-Atmos., 114, D13202, https://doi.org/10.1029/2009JD011862, 2009a.

Tesche, M., Ansmann, A., Müller, D., Althausen, D., Mattis, I., Heese, B., Freudenthaler, V., Wiegner, M., Esselborn, M., Pisani, G., and Knippertz, P.: Vertical profiling of Saharan dust with Raman lidars and airborne HSRL in southern Morocco during SAMUM, Tellus B, 61, 144-164, https://doi.org/10.1111/j.16000889.2008.00390.x, 2009b.

Tesche, M., Wandinger, U., Ansmann, A., Althausen, D., Müller, D., and Omar, A. H.: Ground-based validation of CALIPSO observations of dust and smoke in the Cape Verde region, J. Geophys. Res.-Atmos., 118, 2889-2902, https://doi.org/10.1002/jgrd.50248, 2013.

Tsunematsu, N., Sato, T., Kimura, F., Kai, K., Kurosaki, Y., Nagai, T., Zhou, H., and Mikami, M.: Extensive dust outbreaks following the morning inversion breakup in the Taklimakan Desert, J. Geophys. Res.-Atmos., 110, D21207, https://doi.org/10.1029/2005JD005994, 2005.

Uno, I., Eguchi, K., Yumimoto, K., Takemura, T., Shimizu, A., Uematsu, M., Liu, Z., Wang, Z., Hara, Y., and Sugimoto, N.: Asian dust transported one full circuit around the globe, Nat. Geosci., 2, 557-560, https://doi.org/10.1038/ngeo583, 2009.

Veselovskii, I., Goloub, P., Podvin, T., Bovchaliuk, V., Derimian, Y., Augustin, P., Fourmentin, M., Tanre, D., Korenskiy, M., Whiteman, D. N., Diallo, A., Ndiaye, T., Kolgotin, A., and Dubovik, O.: Retrieval of optical and physical properties of African dust from multiwavelength Raman lidar measurements during the SHADOW campaign in Senegal, Atmos. Chem. Phys., 16, 70137028, https://doi.org/10.5194/acp-16-7013-2016, 2016.

Wandinger, U., Tesche, M., Seifert, P., Ansmann, A., Müller, D., and Althausen, D.: Size matters: Influence of multiple scattering on CALIPSO light-extinction profiling in desert dust, Geophys. Res. Lett., 37, L10801, https://doi.org/10.1029/2010GL042815, 2010.

Weinzierl, B., Ansmann, A., Prospero, J. M., Althausen, D., Benker, N., Chouza, F., Dollner, M., Farrell, D., Fomba, W. K., Freudenthaler, V., Gasteiger, J., Groß, S., Haarig, M., Heinold, B., Kandler, K., Kristensen, T. B., Mayol-Bracero, O.-L., Müller, T., Reitebuch, O., Sauer, D., Schäfler, A., Schepanski, K., Spanu, A., Tegen, I., Toledano, C., and Walser, A.: The Saharan Aerosol Long-range TRansport and Aerosol Cloud Interaction Experiment (SALTRACE): overview and selected highlights, B. Am. Meteorol. Soc., 7, 1427-1451, https://doi.org/10.1175/BAMSD-15-00142.1, 2017.

Wiggs, G. F. S., O’hara, S. L., Wegerdt, J., Van Der Meer, J., Small, I., and Hubbard, R.: The dynamics and characteristics of aeolian dust in dryland Central Asia: possible impacts on human exposure and respiratory health in the Aral Sea basin, Geogr. J., 169, 142-157, https://doi.org/10.1111/1475-4959.04976, 2003.

Wolke, R., Schröder, W., Roland Schrödner, R., and Renner, E.: Influence of grid resolution and meteorological forcing on simulated European air quality: A sensitivity study with the modeling system COSMO-MUSCAT, Atmos. Environ., 53, 110-30, https://doi.org/10.1016/j.atmosenv.2012.02.085, 2012. 
$\mathrm{Xi}, \mathrm{X}$. and Sokolik, I. N.: Dust interannual variability and trend in Central Asia from 2000 to 2014 and their climatic linkages, J. Geophys. Res.-Atmos., 120, 12175-12197, https://doi.org/10.1002/2015JD024092, 2015a.

$\mathrm{Xi}, \mathrm{X}$. and Sokolik, I. N.: Seasonal dynamics of threshold friction velocity and dust emission in Central Asia, J. Geophys. Res.-Atmos., 120, 1536-1564, https://doi.org/10.1002/2014JD022471, 2015b.

$\mathrm{Xi}, \mathrm{X}$. and Sokolik, I. N.: Quantifying the anthropogenic dust emission from agricultural land use and desiccation of the Aral Sea in Central Asia, J. Geophys. Res.-Atmos., 121, 12270-12281, https://doi.org/10.1002/2016JD025556, 2016.

$\mathrm{Xu}, \mathrm{H}$., Wang, X., and Zhang, X.: Decreased vegetation growth in response to summer drought in Central Asia from 2000 to 2012, Int. J. Appl. Earth Obs., 52, 390-402, https://doi.org/10.1016/j.jag.2016.07.010, 2016.
Yamaguchi, N., Ichijo, T., Sakotani, A., Baba, T., and Nasu, M.: Global dispersion of bacterial cells on Asian dust, Sci. Rep., 2, 525, https://doi.org/10.1038/srep00525, 2015.

Zhang, K., O'Donnell, D., Kazil, J., Stier, P., Kinne, S., Lohmann, U., Ferrachat, S., Croft, B., Quaas, J., Wan, H., Rast, S., and Feichter, J.: The global aerosol-climate model ECHAM-HAM, version 2: sensitivity to improvements in process representations, Atmos. Chem. Phys., 12, 8911-8949, https://doi.org/10.5194/acp-12-8911-2012, 2012. 